
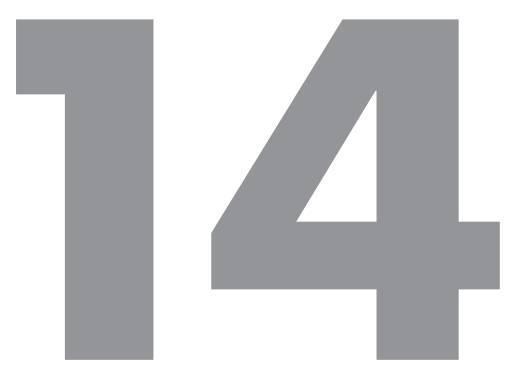

\title{
PETIÇÃO INICIAL: GENERALIDADES
}

A exordial rescisória não diverge dos requisitos fundamentais de toda inicial no âmbito do processo de conhecimento, seguindo o disposto no art. 319 do CPC/2015.

As particularidades que justificam o procedimento especial se refletem na adequação da petição inicial ao procedimento, que possui dispositivos próprios, a partir do art. 968 do mesmo Diploma Processual.

A ação rescisória comporta o pedido de desfazimento da decisão e, a depender das particularidades da lide, eventual pedido de rejulgamento da causa. ${ }^{1}$

Para os casos em que houver a possibilidade de a postulação ser novamente julgada, "o pedido do juízo rescisório está implícito no do juízo rescindente" e "a causa de pedir deve corresponder a uma ou mais das hipóteses do art. 966", ${ }^{2}$ quando a parte pretender ajuizar a ação rescisória.

1 "Dois são os juízos existentes na ação rescisória: o rescindente, pelo qual se pede a nulidade da sentença rescindenda; e o rescisório, em que se pretende seja dada nova decisão à controvérsia." (PEDROSO, Alberto. Ação rescisória cumulação dos "judicia", "rescindens" e "rescisorium". Doutrinas Essenciais de Processo Civil, v. 7, out. 2011. p. 1069; Revista dos Tribunais 176/8, nov. 1948).

2 GONÇALVES, Marcus Vinicius Rios. Direito processual civil esquematizado, p. 564-565. 
Os fundamentos da ação rescisória estão também descritos nos arts. 393, 658, 966 e 967 a 975 do CPC/2015, e em normas esparsas que concluem a malha da base legal referente à ação rescisória no Código. ${ }^{3}$

A legitimidade ativa (para propositura da ação rescisória), nos termos do art. 967 do CPC/2015, recai sobre terceiro juridicamente prejudicado, ${ }^{4}$ Ministério Público, ${ }^{5}$ quem foi parte no processo rescindendo (ou seu sucessor universal ou singular) assim como quem não foi ouvido na demanda em que era obrigatória sua intervenção, ${ }^{6}$ possibilitando a estes, assim, sustentar ao menos um dos vícios rescisórios da decisão de mérito. A legitimidade passiva refere-se ao litisconsórcio necessário formado, via de regra, por todos os que figuraram como parte no processo rescindendo, salvo se um ou alguns deles figurarem como autores na ação rescisória, caso em que, em princípio, somente os remanescentes figurarão no polo passivo.

Convém enaltecer que "a decisão rescindenda pode conter vários capítulos, de forma que devem figurar no polo passivo da rescisória apenas aqueles que possam ter sua esfera jurídica afetada com a desconstituição e o rejulgamento do capítulo de sentença impugnado".

De acordo com o art. 970 do CPC/2015, o prazo para que a parte passiva ofereça defesa será determinado pelo relator e não poderá ser inferior a 15 dias, nem superior a 30 dias. $^{8}$ "Pode o demandado contestar ou reconvir (arts. 335 e

3 Vide, por exemplo, art. 12 da Lei n. 9.882/99 e Lei n. 8.437/92, sobre a concessão de medidas cautelares contra atos do Poder Público. Na área eleitoral, veja-se a LCP 86/1996, e, no ramo trabalhista, o art. 836 da Consolidação das Leis do Trabalho.

$4 \mathrm{O}$ assistente simples que tiver participado da demanda "terá interesse e legitimidade para a rescisória. Em contrapartida, se o terceiro interessado não ingressou como assistente simples, não é atingido pela justiça da decisão e não tem interesse em ajuizá-la. Aquele que poderia ingressar como assistente litisconsorcial será alcançado pela coisa julgada, ingressando ou não, razão pela qual estará legitimado a propor a ação rescisória." (GONÇALVES, Marcus Vinicius Rios. Direito processual civil esquematizado, p. 557).

5 FONSECA, Bruno Gomes Borges da; LEITE, Carlos Henrique Bezerra. Acesso à justiça e ações pseudoindividuais: (i) legitimidade ativa do indivíduo nas ações coletivas. Revista de Processo, São Paulo: RT, v. 37, n. 203, p. 347-366, jan. 2012. p. 348.

6 "É o que pode ocorrer, por exemplo, caso não intimado o Conselho Administrativo de Defesa Econômica, nos casos em que a lei imponha sua intervenção (cf., respectivamente, arts. 31 da Lei 6.385/1976 e 118 da Lei 12.529/2011)”. (MEDINA, José Miguel Garcia. Novo Código de Processo Civil comentado, p. 1392).

7 ALVIM, Angélica Arruda (coord.) [et al.]. Comentários ao Código de Processo Civil, p. 1115.

8 "A fase inicial do procedimento da ação rescisória se difere da do procedimento comum. O despacho que defere a inicial determina a citação do réu não para o comparecimento a audiência de conciliação/mediação, e sim para o oferecimento de resposta. (...) Trata-se de prazo de natu- 
343, CPC). Não pode o réu na ação rescisória reconhecer juridicamente o pedido de rescisão (art. 487, III, CPC), haja vista a indisponibilidade da autoridade da coisa julgada." 9

No campo das provas, como se trata de feito processado diretamente no tribunal, serão admitidas somente provas pré-constituídas (mera análise do feito originário em que se pretender a rescisão) na análise do pedido rescindente. Todavia, quanto ao pedido rescisório (rejulgamento), abre-se a possibilidade de amplitude dos elementos probatórios (oitiva de testemunhas, prova técnica pericial, depoimento pessoal das partes, ofícios para obtenção de informações de terceiros, inspeção judicial, dentre outros), admitindo todas as provas possíveis em direito, inclusive determinando-se diligências quando da necessidade de produção de provas orais.

Quanto aos documentos a instruir a petição inicial, em regra será indispensável juntar a certidão da decisão que se quer rescindir; a certidão do trânsito em julgado, provando que sobre a decisão se operou a coisa julgada; e o comprovante de depósito referente aos 5\% (cinco por cento) do valor da causa, como requisito de procedibilidade da ação rescisória, que, nos termos do art. $968, \mathbb{S} 3^{\circ}$, do CPC/2015, poderá ter sua inicial indeferida nos casos em que o depósito em questão não for efetuado. Ainda, se for o caso, acrescentem-se os demais documentos hábeis à análise do pedido rescisório.

Por fim, em sede destas breves linhas, o requerimento de citação é igualmente importante; saliente-se que, se domicílio do réu for no interior do Estado, a citação será processada mediante carta precatória.

Vejamos, com maior aprofundamento, os requisitos da petição inicial.

\subsection{FUNDAMENTAÇÃO OU HIPÓTESES DE CABIMENTO}

As hipóteses de cabimento da ação rescisória (descritas nos arts. 393, 658, 966 e 967 a 975 do CPC/2015, e em normas esparsas ${ }^{10}$ ) podem ser classificadas

reza mista; cabendo ao juiz estabelecê-lo, não, contudo, ao seu alvedrio, sim dentro de limites preestabelecidos na lei." (MAZZEI, Rodrigo; GONÇALVES, Tiago Figueiredo. Primeiras linhas sobre a disciplina da ação rescisória no CPC/2015. In: DIDIER JR., Fredie (coord.); MACÊDO, Lucas Buril de; PEIXOTO, Ravi; FREIRE, Alexandre. Novo CPC - doutrina selecionada, v. 6: processo nos tribunais e meios de impugnação às decisões judiciais, p. 258).

9 MARINONI, Luiz Guilherme; ARENHART, Sérgio Cruz; MITIDIERO, Daniel. Novo Código de Processo Civil comentado, p. 1031.

10 Por exemplo, Lei n. 9.882/99, que dispõe sobre o processo e julgamento da arguição de descumprimento de preceito fundamental (regulamenta o $\mathbb{1} 1^{\circ}$ do art. 102 da Constituição Federal) e, em seu art. 12, determina expressamente: "Art. 12. A decisão que julgar procedente ou 
pelo critério da natureza dos fundamentos, podendo, assim, ser intrínsecos (por exemplo, violação manifesta a norma jurídica e erro de fato ${ }^{11}$ verificável do exame dos autos) ou extrínsecos (como ocorrente na ofensa à coisa julgada). Portanto, a ação rescisória pode visar ao ataque da sentença por vício na atuação processual do juiz (em evidente concussão, corrupção ou prevaricação) ${ }^{12} \mathrm{e}$, ainda, incompetência absoluta e impedimento (respectivamente, arts. 64 e 144 do $\mathrm{CPC} / 2015)^{13}$ ou vício na atuação das partes (dolo, coação, bem como simulação ou colusão, com fraude à lei) ou vício no próprio teor da sentença (ofensa à coisa julgada ou que tenha sido proferida com base em erro de fato ou prova falsa). Ainda, admite-se a ação rescisória com base em prova nova, hipótese na qual não há qualquer vício da sentença de mérito proferida, a não ser o critério de justiça que deve imperar nas decisões judiciais. ${ }^{14}$

Nesse sentido, dada a diversidade de fundamentos que pode ensejar o cabimento, é fácil perceber que a ação rescisória é submetida a pressupostos específicos (sentença de mérito transitada em julgado e invocação de um dos motivos de rescindibilidade), e, uma vez não atendidos, ocasionar-se-á a extinção do processo sem resolução do mérito. Daí a importância de se ter presentes tais hipóteses e suas respectivas especificidades. ${ }^{15}$

Assim, os casos de cabimento da ação rescisória são estreitos, em rol taxativo, pois, em condições de normalidade, hão de prevalecer os corolários constitu-

improcedente o pedido em arguição de descumprimento de preceito fundamental é irrecorrível, não podendo ser objeto de ação rescisória".

${ }^{11}$ No caso de erro de fato, é especialmente importante, inclusive para evitar ação rescisória indesejada, a manejo dos embargos declaratórios. Nesse sentido, colhe-se o seguinte: "Erro de fato. Admitem-se embargos de declaração para corrigir flagrante e visível erro de fato em que incidiu a decisão, evitando-se os percalços com a eventual interposição de RE, REsp ou o ajuizamento de ação rescisória. Neste sentido: JTACivSP 110/256, 108/287, 100/178, 93/385, 86/318, 53/168; RT 562/146; RTJ 57/145; Lex JTA 105/352; RJTJRS 69/136”. (NERY JÚNIOR, Nelson; NERY, Rosa Maria de Andrade. Código de Processo Civil comentado e legislação extravagante, 4. ed., 1998, p. 1047).

12 NUCCI, Guilherme de Sousa. Código Penal comentado. 5. ed. São Paulo: RT, 2005. p. 994.

13 "Juiz impedido (a referência é à pessoa física e não ao órgão jurisdicional) não pode atuar no processo por falta de imparcialidade objetiva, necessária ao desenvolvimento da jurisdição e que deve estar presente em todas as etapas e fases do processo." (BUENO, Cassio Scarpinella. Curso sistematizado de direito processual civil, 2. ed., 2010, v. 5, p. 377-378).

14 THEODORO JÚNIOR, Humberto. Curso de direito processual civil. 41. ed. Rio de Janeiro: Forense, 2004. v. 1. p. 616-620.

15 NEGRÃO, Theotonio. Código de Processo Civil e legislação processual em vigor. 30. ed. São Paulo, Saraiva, 1999. p. 461. 
cionais da legalidade, da igualdade e do contraditório que informam a segurança jurídica. Como já se disse, até mesmo a existência de ação rescisória atípica por violação de princípios constitucionais se tem enquadrado no inciso V do art. 966 do CPC/2015, o que confirma a regra.

Em aprofundamento do tema, "os fundamentos da ação rescisória podem ser agrupados em quatro grandes categorias. A primeira categoria diz respeito aos fundamentos vinculados ao juiz. A segunda, aos fundamentos vinculados às partes. A terceira, aos vinculados à sentença; e a última, àqueles ligados às provas. Mediante análise da atividade do juiz, das partes; do resultado da sentença, e também das provas, será possível esquematizar os 16 motivos que estão previstos nos incisos do art. 485 e também do inciso II do art. 352" e 1.030 do CPC, ${ }^{16}$ com correspondência aos arts. 966, 393 e 658 do CPC/2015, respectivamente. Passemos a analisá-los, um a um, adotando-se essa classificação.

\subsubsection{Fundamentos vinculados ao juiz}

Aqui se apresentam os seguintes fundamentos do art. 966 do CPC/2015: a) do inciso I, com relação à prevaricação, concussão e corrupção passiva; b) do inciso II, o impedimento; e, por fim, c) do inciso VIII, que trata do erro de fato.

\subsubsection{Prevaricação, concussão, corrupção passiva do juiz}

$\mathrm{Na}$ forma do art. 966, I, do CPC em vigor, a decisão de mérito é rescindível quando proferida por prevaricação, concussão ou corrupção do juiz. A prevaricação, ${ }^{17}$ a concussão ou a corrupção do juiz (art. 966, I) são imperativos morais que viciam a sentença por retirar a confiança necessária depositada em um dos misteres mais nobres dos Poderes do Estado. Essas situações compõem os tipos descritos como crimes nos arts. 319, 316 e 317 do Código Penal (condutas passivas). ${ }^{18}$

16 RIZZI, Luiz Sérgio de Souza. Da ação rescisória. Revista de Processo, v. 26, p. 186.

${ }_{17} \mathrm{Na}$ hipótese de suspeição em razão de prevaricação, será o caso de aplicar o inciso I do art. 485 do CPC. (SANTOS, Ernane Fidélis dos. Manual de direito processual. São Paulo: Saraiva, 1997. v. I. p. 615). Corresponde ao art. 485, inciso I, do CPC/1973 o art. 966, inciso I, do CPC/2015.

18 "Essas três figuras têm caráter penal: prevaricar é retardar ou deixar de praticar ato de ofício ou praticá-lo contra disposição legal para satisfazer interesse ou sentimento pessoal; concussão significa exigir, para si ou para outrem, ainda fora da função ou antes dela, vantagem indevida; e corrupção (aqui a lei alude à corrupção passiva, evidentemente) consiste em pedir ou receber, em virtude da função, vantagem indevida. Conforme se vê na jurisprudência, são raríssimos os casos 
A existência desses delitos dissimula a decisão judicial, que não pode ser considerada propriamente sentença. A ausência do animus iudicandi pode levar o intérprete para o campo dos atos judiciais juridicamente inexistentes, pois falta elemento essencial para se considerar uma sentença. Seja como for, a ação rescisória ou ação declaratória de inexistência permite extirpar tal decisão do sistema, possibilitando o desfazimento da coisa julgada ofensiva às garantias processuais fundamentais; será isso sempre salutar no sistema, pois não se pode privilegiar o processo pelo processo, em detrimento do próprio direito. ${ }^{19}$

Interessante mencionar também que, nas condutas entabuladas no art. 966, I, do CPC/2015, o agente pode ser funcionário público, portanto, não apenas o juiz poderá praticá-las, mas também qualquer servidor da Justiça. ${ }^{20}$ Logo, mesmo que a sentença ou acórdão seja de responsabilidade do julgador pela prática do ato, os auxiliares judiciais, os assistentes e os assessores podem cometer essas condutas no afã de levar o juiz a incidir em erro na elaboração de sua decisão.

A prevaricação (art. 319 do CP) trata da infidelidade ao dever de ofício. Por ela, o juiz sentencia contra disposição expressa de lei a fim de satisfazer interesse ou sentimento pessoal, sem que haja a obtenção de uma vantagem indevida. Havendo vantagem indevida ao juiz infrator, marcada pelo recebimento de uma importância em dinheiro ou por qualquer outra utilidade, então já não será prevaricação, mas concussão ou corrupção passiva, a depender das peculiaridades que as diferenciam.

A concussão (art. 316 do CP) consiste na conduta em que o agente exija para si ou outrem vantagem indevida (um bem ou um favor) em razão da função desenvolvida, sendo certo que há caracterização, mesmo que o agente não esteja na função (por exemplo, juiz que acaba de ser aposentado e continua a oficiar em

de ação rescisória intentada com este fundamento." (WAMBIER, Luiz Rodrigues; TALAMINI, Eduardo. Curso avançado de processo civil. 11. ed. São Paulo: RT, 2010. v. 1. p. 753).

19 Note-se que o atual sistema das tutelas de urgência tem um refinamento particularmente elogiável. Pequenas alterações para inserir o desejo de simplificação processual e diminuição de custas, bem como na direção da adequação à tendência do processo sincrético, embora plenas de boa intenção, em nada tocarão o plano da efetividade. Quer efetividade? Então o problema é de incidência, de aplicação dessas leis, que exige o ato de autoridade e administração até sua conclusão na alteração do plano fático. O problema é de aparelhamento do Estado-juiz. Uma coisa é a decisão e outra é a realidade - dois planos distintos, que devem ter total atenção de nossas autoridades.

20 BARIONI, Rodrigo Otávio. Ação rescisória e recursos para os tribunais superiores, p. 68. 
alguns processos) ou antes de assumi-la (por exemplo, aquele que passou no concurso e sabe a vara em que oficiará). Então, no caso específico, o juiz que elabora e apresenta um esboço da sentença amplamente favorável a uma das partes, por si ou por interposta pessoa, deixando claro que somente exarará a sentença naqueles termos se houver a paga de R \$100.000,00, e mais, ameaça a parte interessada de não julgar o feito, paralisando-o indefinidamente, caso não haja o pagamento, pratica concussão. Na concussão, o juiz (servidor público) se lança à frente e exige dinheiro, um bem ou um favor para fazer ou deixar de fazer algo. O núcleo do tipo é exigir; o ato unilateral de exigir já configura a concussão. $^{21}$

Na corrupção passiva (art. 317 do CP), o juiz solicitará, pedirá ou simplesmente receberá a vantagem indevida para exarar ou deixar de exarar a sentença em contrariedade ao que dita a lei. Naquele mesmo exemplo aventado, caso não haja ostensividade do juiz em exigir a vantagem, mas apenas solicitação, pedido ou mesmo o recebimento pelo aceite da vantagem ofertada pela parte, então estará configurada a corrupção passiva. O núcleo do tipo é solicitar ou receber; o ato unilateral de solicitar já configura a corrupção passiva, mas nada impede que seja configurado também pela atuação da parte, pelo recebimento, configurando uma pactuação entre o juiz e a parte.

No caso de acórdão, a questão sobre o cabimento da ação rescisória não é pacífica. $^{22}$ A prevalência dos votos envolve sempre um colegiado, e há entendimentos apontando para a necessidade de ser apurado o grau de contaminação da decisão pela atuação dos integrantes do órgão judicante, ou seja, se a alegação é suficiente para alterar o resultado do julgado, abrir-se-á o cabimento; caso contrário, não haverá cabimento da ação rescisória, pois não há utilidade ou interesse na anulação de um ou de parte dos votos. ${ }^{23}$

${ }^{21}$ CAPEZ, Fernando. Curso de direito penal. 6. ed. São Paulo: Saraiva, 2007. v. III: Parte especial. p. 447.

22 "É predominante o entendimento de que, nos órgãos colegiados, faz-se suficiente a prática de ato definido como prevaricação, concussão ou corrupção por um de seus integrantes, que tenha efetivamente participado do julgamento, para que a decisão possa ser rescindida por esse fundamento. Isso por uma razão muito simples: nos órgãos colegiados, o julgamento é a reunião de vontades individuais. Se uma delas está contaminada por um dos vícios repudiados pela lei, o resultado da reunião destas vontades também estará.” (BUENO, Cassio Scarpinella. Código de Processo Civil interpretado. In: MARCATO, Antonio Carlos (Coord.). São Paulo: Atlas, 2004. p. 1475).

${ }^{23}$ Em sentido contrário, a doutrina afirma que "para a admissibilidade da rescisória basta que se alegue (e para a procedência que tenha havido) prevaricação, concussão ou corrupção passiva 
É ponto pacífico que, para o ajuizamento da ação rescisória com fundamento no art. 966, I, do CPC atual, não se exige a prévia condenação criminal do juiz, pois a prova da conduta atípica será ventilada na própria rescisória. ${ }^{24}$ Todavia, se existir processo criminal, poderá seu resultado refletir no julgamento da rescisória, a depender de ser a sentença de procedência ou improcedência da ação criminal, pois é julgamento que interfere diretamente no convencimento judicial, por ser produzido em sede própria e, no mais das vezes, com maior rigor quanto à matéria. Essa influência só não se efetua quando a absolvição ocorre por falta de provas ou falta de elementos para se aferir a existência ou inexistência material do crime, quando as provas deverão ser colhidas nos próprios autos da ação rescisória. ${ }^{25}$

\subsubsection{Imparcialidade do juiz: impedimento do juiz e juízo absolutamente incompetente}

O princípio da imparcialidade, zelando pela plena capacidade subjetiva do juiz, deve estar presente durante todo o processo. Tamanha é a sua importância que, para resguardo desse corolário, até mesmo após findo o processo e transitada em julgado a sentença de mérito, pode ser denunciado seu descumprimento, abrindo o cabimento do pedido rescisório com base em impedimento do juiz ou incompetência absoluta do juízo, conforme o art. 966, II, do $\mathrm{CPC} / 2015 .{ }^{26}$

Além disso, "a imparcialidade do juiz (ausência de impedimento) e a competência do juízo (ausência de incompetência absoluta) são pressupostos processuais de validade. A falta de um deles enseja a nulidade da decisão proferida; transitada em julgado a decisão, passam a constituir causa de rescindibilidade sua". ${ }^{27}$

de um dos membros do colégio, cujo voto haja concorrido para a formação da maioria, ou eventualmente da unanimidade no julgamento”. (MOREIRA, José Carlos Barbosa. Comentários ao Código de Processo Civil. Rio de Janeiro: Forense, 1978. v. V. p. 144).

${ }^{24}$ MARINONI, Luiz Guilherme; ARENHART, Sérgio Cruz; MITIDIERO, Daniel. Novo Código de Processo Civil comentado, p. 1022.

${ }^{25}$ MOREIRA, José Carlos Barbosa. Comentários ao Código de Processo Civil, 15. ed., v. V, p. 122.

${ }^{26}$ O impedimento é vício do juiz, enquanto a incompetência é um vício de juízo. (MEDINA, José Miguel Garcia. Código de Processo Civil comentado. São Paulo: RT, 2011. p. 493).

27 MAZZEI, Rodrigo; GONÇALVES, Tiago Figueiredo. Primeiras linhas sobre a disciplina da ação rescisória no CPC/2015. In: DIDIER JR., Fredie (coord.); MACÊDO, Lucas Buril de; PEIXOTO, Ravi; FREIRE, Alexandre. Novo CPC - doutrina selecionada, v. 6: processo nos tribunais e meios de impugnação às decisões judiciais, p. 251. 
Os impedimentos ${ }^{28}$ que provocam o comprometimento da sentença e geram posterior possibilidade de rescisão estão previstos no CPC. São eles: a) dos arts. $45,47, \mathbb{S} 1^{\circ}$, e 51 , prevendo algumas hipóteses de incompetência territorial; b) do art. 62, com relação aos casos de incompetência absoluta (em razão da matéria de julgamento, da pessoa ou função); c) do art. 144, afastando as hipóteses em que o juiz possa ter algum interesse na causa; e d) do art. 147, que impede dois juízes parentes de oficiar no mesmo processo. Essas hipóteses são taxativas, não comportando ampliação, nem por analogia. No mais, esses dispositivos devem ser interpretados em conjunto com os respectivos regimentos internos dos tribunais e leis de organização judiciária. ${ }^{29}$

Esclareça-se que a incompetência relativa (em razão do valor e do território, na maioria das hipóteses) é prorrogável (art. 65 do CPC/2015), está sob o regime do ônus da oposição da exceção de incompetência (art. 63, $\mathbb{S} 3^{\circ}$, do CPC/2015) e, por isso, permanece incólume o princípio invocado, não sendo passível de fundamentar ação rescisória, ${ }^{30}$ bem como está fora da hipótese de cabimento a motivação na suspeição (art. 66 do CPC/2015).

No caso de ação rescisória fundada por incompetência absoluta, caberá ao tribunal apenas realizar o juízo rescindente, devendo os autos ser remetidos ao tribunal competente para novo julgamento da causa, salvo se for o tribunal competente para o julgamento ${ }^{31}$. Por óbvio que a inobservância da remessa dos autos para o rejulgamento ensejará a reincidência do vício que funda a ação rescisória. ${ }^{32}$

\subsubsection{Erro de fato}

A ação rescisória também é cabível com fundamento no erro de fato, verificável do exame dos autos, conforme descrito no art. 966, VIII e $\mathbb{S} 1^{\circ}$, do CPC/2015.

28 "O impedimento é vício arguível em ação rescisória, e não em impugnação à execução de decisão judicial.” (STJ - AgRg no REsp 1.243.311/SP, Rel. Ministro Paulo de Tarso Sanseverino, $3^{\text {a }}$ T., DJe 05.02.2015).

29 YARSHELL, Flávio Luiz. Ação rescisória - juízo rescindente e rescisório, p. 296.

30 "A incompetência relativa não é motivo para rescisão da coisa julgada." (MARINONI, Luiz Guilherme; ARENHART, Sérgio Cruz; MITIDIERO, Daniel. Novo Código de Processo Civil comentado, p. 1022).

31 RIZZARDO, Arnaldo. Limitações do trânsito em julgado e desconstituição da sentença. Rio de Janeiro: Forense, 2009. p. 305.

32 O Anteprojeto do novo Código de Processo Civil, em sua primeira versão, excluiu a possibilidade do embasamento da ação rescisória na incompetência absoluta, permanecendo intacta a previsão quanto ao impedimento do juiz (art. 919, II, do Anteprojeto do novo CPC). 
No julgamento de mérito, o convencimento do magistrado pode se embasar em fatos errôneos, que, por sua vez, podem ser o motivo determinante do resultado do julgamento. Nessa hipótese, autoriza-se a propositura da ação rescisória, uma vez evidenciado o nexo causal entre a sentença e a sua fundamentação no erro de fato, uma vez que, se não houvesse sido reconhecido, o dispositivo decisório seria outro. ${ }^{33}$

É preciso não confundir o erro de fato com o erro de interpretação de fato. O erro de fato não tem preponderância na justiça ou injustiça da decisão, mas sim na existência ou inexistência equívoca de um fato decisivo declarado na sentença. Por óbvio, a má interpretação do fato, decorrente da justiça ou injustiça da decisão, não se apresenta como motivo a ensejar o cabimento da ação rescisória. $\mathrm{O}$ erro de fato que abre o cabimento da ação rescisória é aquele ocasionado por erro na suposição do juiz no encadeamento de seu raciocínio ou na análise das provas existentes no processo. Forçoso que simplesmente o juiz suponha (conjecture ou faça crer) o fato como existente ou inexistente, fato esse a respeito do qual restou ausente controvérsia. Essa assertiva decorre da aplicação do $\mathbb{S} 1^{\circ}$ do art. 966, que é diretamente relacionado ao inciso VIII do mesmo artigo. ${ }^{34}$

A doutrina aponta exemplo peculiar: "numa ação de cobrança de um crédito originário de um contrato, ao contestar, o réu diz que cumpriu o contrato, mas disto não faz prova, entretanto, no corpo dos autos, quando se trabalha com a prova, vem um comprovante, uma certidão de nascimento, de que o réu era absolutamente incapaz à época em que celebrou o contrato, e o juiz julga procedente a ação porque não houve o cumprimento da obrigação; é evidente que o julgado

33 "Para que o erro de fato legitime a propositura da ação rescisória, é preciso que tenha influído decisivamente no julgamento rescindendo. Em outras palavras: é preciso que a sentença seja efeito do erro de fato; que haja entre aquela e este um nexo de causalidade." (NERY JÚNIOR, Nelson; NERY, Rosa Maria de Andrade. Código de Processo Civil comentado e legislação extravagante - comentários ao art. 485, IX, do CPC. 7. ed. rev. e ampl. São Paulo: RT, 2003. p. 831).

${ }^{34}$ Colhe-se a seguinte lição doutrinária, ao dissertar sobre o inciso IX e parágrafos do art. 485 do Código de Processo Civil: "O texto é de difícil compreensão. Se não houve pronunciamento judicial sobre o fato, como é possível ter havido erro? O erro, exatamente é o acolhimento de um fato inexistente como existente, ou o contrário. O que a lei quer dizer, porém, é o seguinte: o erro de fato, para ensejar a rescisória, não pode ser aquele que resultou de uma escolha ou opção do Juiz diante de uma controvérsia. O erro, no caso relevante, é o que passou desapercebido pelo Juiz, o qual deu como existente um fato inexistente ou vice-versa. Se a existência ou inexistência do fato foi ponto controvertido e o Juiz optou por uma das versões, ainda que erradamente, não será a rescisória procedente”. (GRECO FILHO, Vicente. Direito processual civil brasileiro. 4. ed. São Paulo: Saraiva, 1989. v. 2. p. 379). 
se contaminou por um erro de fato. Houve erro de fato porque embora provado, no processo, um fato impeditivo da realização do negócio jurídico, (...) o ato civil praticado por agente absolutamente incapaz não pode produzir efeitos. E o juiz, ao desconsiderar esse fato, na sua suposição - suposição porque ele não fez constar da sentença: o menor era capaz - contrariou implicitamente as provas dos autos, dos quais, repetimos, estava constando um fato impeditivo - motivo de nulidade". 35

Nesse contexto também se insere a lição de que na ação rescisória por erro de fato não se admitirá a produção de provas novas, sendo vedada a abertura da instrução para carrear aos autos outros elementos probatórios. ${ }^{36} \mathrm{O}$ âmbito de análise probatória se subsome ao contexto probatório hermético do processo em que se apresenta na sentença rescindenda.

Não se cogita de valorizar axiologicamente o fato, mas de critério objetivo do fato existente anotado como inexistente, ou vice-versa, em que se fundou a sentença, e, fosse interpretado corretamente, haveria a mudança no resultado da sentença meritória transitada em julgado. Note-se que é imprescindível que esse fato não tenha sido objeto do exercício do contraditório, nem de manifestação decisória do juiz. ${ }^{37}$ Trata-se de decorrência lógica do $\mathbb{S} 1^{\circ}$ do art. 966 do CPC/2015.

Configura-se o caso típico quando o documento juntado e em que se funda a sentença é dado como válido, mas, na verdade, o documento é falso; ou, ainda, quando ocorre fato inequívoco nos autos e a decisão simplesmente nega sua existência, como no caso de um documento juntado aos autos e sobrevinda sentença pela ausência do documento - o erro é patente. ${ }^{38}$

35 RIZZI, Luiz Sérgio de Souza. Da ação rescisória. Revista de Processo, v. 26, p. 187.

36 GONÇALVES, Marcus Vinicius Rios. Direito processual civil esquematizado, p. 563.

37 Veja, neste julgado, a improcedência da ação rescisória em virtude da expressa manifestação dos julgadores: "Ação Rescisória. Erro de fato. Caso em que houve a expressa manifestação da Turma julgadora na decisão rescindenda acerca do fato apontado pelo autor como apto a ensejar o corte rescisório, circunstância que obsta a pretensão de desconstituição do acórdão rescindendo por erro de fato. Ação rescisória improcedente”. (TRT-4 - AR 00210869820175040000, julgado em 23.03.2018, $2^{a}$ Seção de Dissídios Individuais).

38 "O erro de fato, capaz de justificar o ajuizamento da ação rescisória, nos termos dos $\mathbb{S} 1^{\circ}$ e $2^{\circ}$ do inciso IX do art. 485 do CPC, somente se configura quando o decisum rescindendo tenha admitido como fundamento um fato inexistente, ou tenha considerado inexistente um fato efetivamente ocorrido; sendo indispensável que, em qualquer hipótese, não tenha havido pronunciamento judicial sobre o fato. A via rescisória não é adequada para a aferição da existência de injustiça do decisum rescindendo, tampouco para corrigir interpretação equivocada dos fatos, reexaminar ou complementar as provas produzidas no processo originário. Recurso 
Em suma, são condições para admissibilidade da ação rescisória: ${ }^{39}$ a) a inexistência de controvérsia ou pronunciamento judicial sobre o fato reputado com cômputo errôneo; b) prova do erro com o simples exame do processo que constituiu a sentença rescindenda, sendo vedada a dilação probatória do erro na rescisória; e c) o erro ter relação de causalidade com o resultado da sentença. ${ }^{40}$

\subsubsection{Fundamentos vinculados às partes}

Aqui analisaremos os seguintes fundamentos do art. 966 do CPC/2015: a) do inciso III, o dolo ou coação da parte vencedora em detrimento da parte vencida; b) também do inciso III, a fraude à lei pela simulação ou conluio entre as partes; e c) do inciso VIII, a renúncia ao direito sobre o qual se funda a ação, o reconhecimento jurídico do pedido e a transação. ${ }^{41}$ Por derradeiro, as hipóteses

especial conhecido e desprovido.” (STJ - REsp 653.613/DF, Rel. Ministra Laurita Vaz, 5 a Turma, julgado em 26.05.2009, DJe 15.06.2009). Corresponde aos $\mathbb{S} \mathbb{S} 1^{\circ}$ e $2^{\circ}$ do inciso IX do art. 485 do CPC/1973 o $\mathbb{1} 1^{\circ}$ do inciso VIII do art. 966 do CPC/2015.

$39 \mathrm{O}$ não atendimento da condição da ação leva à extinção da ação rescisória. Vide precedente: "Agravo inominado. Decisão monocrática que nega seguimento à ação rescisória. Ausência dos requisitos necessários à demanda. Art. 485 do Código de Processo Civil. Inexistência de violação a dispositivo de lei, prova falsa ou erro de fato. Extinção do feito sem julgamento de mérito. Aplicação do art. 557 do Código de Processo Civil. Possibilidade na espécie. Desprovimento do recurso. Não demonstrado o erro de fato do julgamento e não havendo irregularidade na aplicação da Lei, ou seja, não estando preenchidos os requisitos presentes nos inc. V e IX do art. 485, tampouco quaisquer outros do referido rol, tem-se que o autor não possui interesse de agir para a ação rescisória. Por essa razão, a extinção do processo é medida que se impõe, conforme os arts. $3^{\circ}$ e 267 , inciso VI e $\mathbb{3} 3^{\circ}$, do Código de Processo Civil”. (TJSC - Agravo - $\$ 1^{\circ}$ art. 557 do CPC - em AR 443.737/SC 2010.044373-7, Origem: Presidente Getúlio, Rel. Des. Pedro Manoel Abreu, Órgão Julgador: Grupo de Câmaras de Direito Público, julgamento e publicação: 28.02.2012). Correspondem aos arts. 485, incisos V e IX, e 557 do CPC/1973, respectivamente, os arts. 966, incisos V e VIII, e 932 do CPC/2015.

40 "Em face do disposto no n. IX e nos $\mathbb{S} 1^{\circ}$ e $2^{\circ}$ do art. 485 , do Código, são seis os requisitos para a configuração do erro de fato: a) deve dizer respeito a fato(s); b) deve transparecer nos autos onde foi proferida a decisão rescindenda, sendo inaceitável a produção de provas, para demonstrá-lo, na ação rescisória; c) deve ser causa determinante da decisão; d) essa decisão dever ter suposto um fato que inexistiu ou inexistente um fato que ocorreu; e) sobre este fato não pode ter havido controvérsia; f) finalmente, sobre o fato não deve ter havido pronunciamento judicial." (RIZZI, Luiz Sérgio de Souza. Ação rescisória. São Paulo: RT, 1979. p. 118). Corresponde aos $\mathbb{S} 1^{\circ}$ e $2^{\circ}$ do inciso IX do art. 485 do CPC/1973 o $\$ 1^{\circ}$ do inciso VIII do art. 966 do CPC/2015.

${ }^{41}$ O caráter das concessões recíprocas é essencial para a transação. Assim, para as partes, "nessa troca de prestações recíprocas, na suportabilidade de sacrifícios para cada uma, reside o núcleo 
previstas no art. 658 do CPC/2015, consubstanciadas na rescisão de partilha hereditária julgada por sentença. Passemos à análise.

\subsubsection{Dolo ou coação da parte vencedora e simulação ou colusão das partes}

$\mathrm{O}$ processo judicial exige lealdade e boa-fé entre as partes - art. $5^{\circ}$ do CPC/2015. Quando houver o trânsito em julgado da sentença de mérito com dolo da parte vencedora em detrimento do juiz ou da parte vencida; ou coação de uma parte contra outra, haverá cabimento da ação rescisória. ${ }^{42-43}$

O dolo aqui versado se revela em um conjunto de meios, ardis e maquinações que implicam o impedimento do ex adverso de realizar a sua defesa ou que desvie o juiz da verdade.

Esse dolo da parte vencedora é caracterizado como dolo processual, que faz o julgador emitir sentença com base justamente na manobra desleal da parte. ${ }^{44}$

Poder-se-ia questionar se o dolo rescisório estaria presente no silêncio, a simples omissão de fatos que poderiam implicar outro desfecho da ação. A dúvida não resiste a uma melhor análise, sendo certo que o dolo rescisório não se configura no simples silêncio da parte a quem aproveitaria o fato omisso. O processo não admite surpresas, e, embora seja um processo mal instruído por força da omissão das partes, mas em que foram dadas todas as oportunidades de ampla defesa e contraditório, não haverá que se falar em ação rescisória. Ainda, restará claro que a parte que se prejudicará com a apresentação da prova não terá obrigação de apresentá-la, e isso nem se cogita da implicação na ação rescisória, pois será conduta atípica para tal fim.

vital da transação. Se não houver essa reciprocidade, não há que falarem transação, mas em liberalidade”. (MALUF, Carlos Alberto Dabus. A transação no direito civil. São Paulo: Saraiva, 1985. p. 32).

42 A redação do inciso III do art. 485 do CPC foi "parcialmente inspirada no art. 395, inciso 1 do Código de Processo Civil Italiano”. KLIPPEL, Rodrigo; BASTOS, Antônio Adonias. Manual de processo civil. Rio de Janeiro: Lumen Juris, 2011. p. 979. Corresponde ao art. 485, inciso III, do CPC/1973 o art. 966, inciso III, do CPC/2015.

43 "Para que possa ensejar a rescisória, é preciso que isso tenha sido determinante para o resultado e que aquele que violou o dever de lealdade e boa-fé, ou fazendo uso de ardis para induzir a erro o adversário, ou fazendo uso da coação, tenha saído vitorioso". (GONÇALVES, Marcus Vinicius Rios. Direito processual esquematizado, p. 560).

${ }^{44} \mathrm{O}$ dolo processual é verificado quando "as supostas falsas alegações tenham induzido a erro o órgão julgador” (STJ - Ag Rg na AR 3.819/RJ, Rel. Ministro Antonio Carlos Ferreira, 2 ${ }^{\text {a Se- }}$ ção, julgado em 09.09.2015). 
Ainda, verifica-se facilmente que deve estar presente o nexo causal entre a omissão e a sentença. Levado em conta o dolo, se a sentença se mantiver inalterada, por certo não se configurará o dolo rescisório.

Já a coação incide "quando ela incute no adversário fundado temor de dano iminente e considerável à sua pessoa, à sua família ou a seus bens. Vale ressaltar que, 'se o dolo ou a coação foi usado para impedir que o réu tomasse conhecimento real da ação, será necessário que o processo retome da fase de citação, prosseguindo a partir daí. Se o dolo ou coação foi usado para obstar a produção de provas, o processo reiniciará a partir dessa fase." ${ }^{\prime 4}$

Quando as partes praticam a simulação, elas usam a postulação com o intuito de lesar terceiros (o Código Civil prevê hipóteses de tal conduta em seu art. $167, \mathbb{S} 1^{\circ}$ ); na colusão, ambas visam utilizar a demanda para atingir um fim não permitido pela lei. ${ }^{46}$

Para os casos de dolo ou coação, "há, pois, divergência não intencional entre a declaração e a vontade não manifestada (sobre a questão, cf., ainda, Paula Costa e Silva, Acto e processo, p. 543 ss.). Diversamente, no caso de simulação ou coação entre as partes, há divergência intencional entre a vontade real e a declarada (a respeito, cf. também art. 142 do CPC/2015)". ${ }^{47}$

A título de exemplo de simulação, “'A' e 'B', mediante ajuste malicioso, litigam em ação possessória que tem como objeto bem sob o domínio e posse de 'C'”, ${ }^{48}$

No processo, vige o princípio da menor intervenção possível, devendo o Poder Judiciário se aproximar DE dar o mesmo bem que seria obtido de modo não interventivo quando do cumprimento voluntário do direito, sem prejuízo dos acréscimos indenizatório e moratório. Quando as partes, em conluio, buscam, pelo processo judicial, obter um resultado que não alcançariam sem o processo, ocorre a fraude à lei. Assim, em todas as hipóteses do art. 80 do CPC/2015 ou manobras ou engodos fraudulentos em geral, uma vez presente qualquer fundamento que enseje nítida produção do resultado da causa em benefício do litigante de má-fé, estará caracterizada a hipótese rescisória.

Tal hipótese se configura, por exemplo, quando, atuando em conluio com a parte contrária, o advogado do sucumbente não recorre. Outro caso que se conforma com a norma em comento ocorre quando a parte que acabou de ser citada

45 GONÇALVES, Marcus Vinicius Rios. Direito processual esquematizado, p. 560.

46 ALVIM, Angélica Arruda (coord.) [et al.]. Comentários ao Código de Processo Civil, p. 1104.

47 MEDINA, José Miguel Garcia. Novo Código de Processo Civil comentado, p. 1380.

48 ALVIM, Angélica Arruda (coord.) [et al.]. Comentários ao Código de Processo Civil, p. 1104. 
é mantida em cárcere privado a mando da parte contrária, com o fito de expirar o prazo da defesa, e, de fato, não consegue se defender no prazo e sobrevém a sentença de procedência à revelia, com o trânsito em julgado. Ainda, pode ser caracterizada a conduta dolosa para a ação rescisória: na citação por edital de uma pessoa quando facilmente localizável e que poderia ser citada pelos meios ordinários; na sorrateira e furtiva retirada de documento dos autos; na interceptação de uma correspondência que serviria de prova para o adversário; em processo de anulação de casamento, quando uma parte faz alegações infundadas e a outra parte aceita; ou, ainda, forjam-se provas que contenham inverdades, alterando os fatos ou incluindo fatos inexistentes para inquinar na procedência irreal do processo. Em todos esses casos, o conluio restará caracterizado, alinhando-se com a fraude à lei. ${ }^{49}$

De outro lado, o nível de ajuste pode se dar até mesmo entre demandante e demandado, na chamada colusão entre partes. ${ }^{50} \mathrm{~A}$ combinação do ajuste entre as partes com o fim de engendrarem manobras para a fraude à lei (ato simulado) e a efetiva produção desse resultado desejado (fim proibido por lei), uma vez ausente a possibilidade de o órgão julgador obstar os efeitos do ato, são características da colusão processual que abre o cabimento à ação rescisória. ${ }^{51}$

Convém enaltecer que, para os casos de simulação e colusão, em conformidade com o art. $975, \mathbb{S} 3^{\circ}$, o termo inicial do prazo decadencial de dois anos para o ajuizamento da ação rescisória difere da regra geral, já que referido prazo se iniciará quando o terceiro prejudicado ou o Ministério Público obtiverem ciência da simulação ou da colusão.

Ressalta-se, ainda, que a desconstituição da resolução de mérito por meio da ação rescisória fundada nos casos previstos no art. 966, III, do CPC/2015 apenas não atingirá o litisconsórcio quando se tratar de não unitário, e a sentença ou acórdão comportar diferentes capítulos para cada qual. ${ }^{52}$

49 Trata-se de "má-fé ou deslealdade no processo rescindendo, em que a parte levou o julgador à decisão impugnada". (RTFR $157 / 51$ e 55). (NEGRÃO, Theotonio; GOUVÊA, José Roberto Ferreira. Código de Processo Civil e legislação processual em vigor. 39. ed. São Paulo: Saraiva, 2007, art. 485, nota 15 ).

50 "Dolo, segundo Clóvis Beviláqua, é o emprego de um artifício astucioso para induzir alguém à prática de um ato negocial que o prejudica e aproveita ao autor do dolo ou a terceiro.” (DINIZ, Maria Helena. Comentário ao art. 145. In: SILVA, Regina Beatriz Tavares da (Coord.). Novo Código Civil comentado. 7. ed. São Paulo: Saraiva, 2010. p. 126).

51 MOREIRA, José Carlos Barbosa. Comentários ao Código de Processo Civil, 15. ed., v. V, p. 123.

52 YARSHELL, Flávio Luiz. Ação rescisória - juízo rescindente e rescisório, p. 312. 


\subsubsection{Rescisão de partilha hereditária julgada por sentença}

Com a morte de uma pessoa, abrem-se as incertezas de natureza objetiva e subjetiva, respectivamente, sobre os bens existentes sujeitos à herança e quanto à existência de herdeiros e legatários. ${ }^{53} \mathrm{~A}$ aplicação do princípio da saisine (transmissão automática dos bens aos sucessores) não é suficiente, pois será necessário documentar essa transmissão, ou seja, operar os efeitos constitutivos da partilha (não mero efeito declaratório), e, se houver mais que um sucessor, processar-se-á a individuação dos bens para cessar o estado condominial. ${ }^{54}$

Assim, apresentam-se a forma instrumental do inventário, do arrolamento sumário e da partilha. Os objetivos são a descrição e avaliação dos bens da herança e a identificação das pessoas que sucederam o falecido, propiciando a decisão que determine a extensão do direito de cada um dos herdeiros sobre o monte mor,

53 Aliás, amealhar bens durante a vida começa com a luta pela subsistência. Diz a doutrina: "en el empleo de energía por el hombre para subsistir por sí mismo es donde encontra su ponto de partida el trabajo humano. La subsitencia comprende la idea de alimento, vestido y vivienda, en función de la diversidad climática del ambiente en el que se desenvuelve". (GHERSI, Carlos Alberto. Cuantificación económica - Valor de la vida humana - Indenización por lesiones y muerte, estratificación socioeconómica y cultural, proceso de cunsumo y ahorro, meritocracia y derecho de chance. 4. ed. Buenos Aires: Astrea, 2008. p. 130). Ainda, acresça-se que "en primer lugar a idea de cunsumo debe ser colocada en la base del proceso social". (DOUGLAS, Mary; ISHERWOOD, Baron. El mundo de los bienes. Hacia una antropología del cunsumo. Cidade del México: Grijalbo, 1990. p. 18).

${ }^{54} \mathrm{O}$ Droit de Saisine significa que a abertura da sucessão ocorre no exato momento da morte do de cujus, e com ela se dá a transferência automática da posse e propriedade da herança aos herdeiros legítimos e testamentários. Dispõe o Código Civil: "Art. 1.784. Aberta a sucessão, a herança transmite-se, desde logo, aos herdeiros legítimos e testamentários. Art. 1.791. Parágrafo único. Até a partilha, o direito dos coerdeiros, quanto à propriedade e posse da herança, será indivisível, e regular-se-á pelas normas relativas ao condomínio”. Tal princípio não se aplica ao legatário: "Art. 1.923. Desde a abertura da sucessão, pertence ao legatário a coisa certa, existente no acervo, salvo se o legado estiver sob condição suspensiva. $\mathbb{\$} 1^{\circ}$ Não se defere de imediato a posse da coisa, nem nela pode o legatário entrar por autoridade própria”. Em que pese a prevalência do "princípio do Droit de Saisine, não se pode considerar a partilha um ato de transferência dominial inter heredes, porque a estes já precedentemente se transmitira a herança (...) Por isso se diz que a partilha, tal qual a divisão (CC, art. 631), tem efeito declaratório e não atributivo da propriedade". (PEREIRA, Caio Mário da Silva. Instituições de direito civil. 3. ed. Rio de Janeiro: Forense, 1980. v. VI. p. 288). Aliás, o cônjuge supérstite passou a ser herdeiro necessário no Código Civil de 2002. (MALUF, Carlos Alberto Dabus; MALUF, Adriana Caldas do Rego Freitas Dabus. Da ordem de vocação hereditária e a sucessão do cônjuge e do companheiro na nova ordem legal. Revista do Instituto dos Advogados de São Paulo, v. 30, jul. 2012. p. 241). 
se houver pluralidade de habilitados, culminando na liquidação da herança. Com a partilha, cessa a indivisão condominial entre os habilitados com relação aos bens, passando o patrimônio, agora dividido, especificado e individualizado, à propriedade particular de cada herdeiro, ressalvada a copropriedade em bens especificados. Assim, os quinhões são individualizados, realizando-se o comando da sentença de partilha dos bens inventariados entre os sucessores do de cujus.

Por sua vez, como qualquer ato jurídico, a partilha está sujeita a vícios que podem implicar nulidade ou anulabilidade. Sendo a partilha julgada por sentença, apresenta-se também no processo a possibilidade de rescindibilidade, uma vez preenchidos os requisitos, na forma dos arts. 658 e 966 do CPC/2015.

Assim, a partilha sentencial está sujeita à rescindibilidade nos casos específicos do art. 966 do CPC/2015 e também nas hipóteses previstas no art. 658 do mesmo Código, consubstanciada, nos termos do art. 657, em decisão que é fruto de erro, dolo ou coação; ${ }^{55}$ viabilizada pela intervenção inadequada de menor ou incapaz ${ }^{56}$ quando preteridas formalidades legais essenciais ao ato (espécie do gênero já previsto no art. 966, V, do CPC/2015); quando preterido herdeiro ou quando incluída a pessoa que se passe por beneficiária da herança sem que detenha, de fato e de direito, essa qualidade.

55 Em lição oportuna, Pontes de Miranda confere: “a) dolo: pode ter consistido em operações para diminuir o que tocaria ao quinhão de algum herdeiro, ou de alguns herdeiros, ou de todos, com a compra a alto preço, fictício ou injustificável, de algum bem que fora legado com indicação específica, ou colocar-se no quinhão 'a' o que estava deteriorado e no quinhão 'b' o que estava em bom estado (a partilha tinha de ser com igualdade); b) coação: a anulabilidade por violência ou coação pode resultar de coação exercida contra algum herdeiro, ou alguns herdeiros, ou mesmo contra todos os herdeiros, que fizeram partilha amigável, quer por escritura pública, quer por termo nos autos, quer por escrito particular, homologada pelo juiz, e; c) erro: só o erro de fato e não o erro de direito configura vício de consentimento; o erro de direito pode se configurar na equivocada qualificação de herdeiro; (...) não sendo a partilha fonte atributiva de domínio não pode pretender-se reconhecer eficácia ao negócio jurídico que tenha declarado propriedade inexistente. O erro de fato, na espécie, somente pode dizer respeito aos termos da própria partilha, ou seja, no que diga respeito à formação dos quinhões, de maneira a lesar injustamente um ou alguns herdeiros, por falsa noção da realidade. Aliás, a única diferença prática, em nosso Direito, entre dolo e erro reside na causa do vício de consentimento: se a falsa noção da realidade provém de caso fortuito, o caso é de erro substancial (...) se provém de malícia ou ardil de outrem, ocorre o dolo civil”. (PONTES DE MIRANDA, Francisco Cavalcanti. Comentários ao Código de Processo Civil. Rio de Janeiro: Forense, 1977. v. XIV, p. 270).

56 "A incapacidade, para autorizar a rescisória, é apenas a relativa, porque a absoluta conduz à nulidade de pleno direito e não apenas à rescindibilidade.” (THEODORO JÚNIOR, Humberto. Partilha: nulidade, anulabilidade e rescindibilidade. Doutrinas Essenciais Família e Sucessões, v. 6, p. 1171-1188, ago./2011. p. 1178). 
A ação rescisória é específica para desconstituição de sentença de mérito passada em julgado, abrangendo, portanto, somente a partilha judicial oriunda de procedimento contencioso, capaz de produzir a sentença de mérito. Ainda que judicial, se a participação do magistrado limitar-se à homologação da partilha proposta pelas partes, não será caso de ação rescisória, pois não haverá cunho decisório para tanto; se existente vício, desafiará ação anulatória.

Note-se, por fim, que a legitimidade para propositura da rescisória com fundamento no art. 658, III, do CPC/2015 requer que o herdeiro prejudicado esteja sujeito à autoridade da res judicata, ou seja, o autor da ação rescisória é aquele que foi prejudicado pela partilha deferida em juízo, tendo participado da relação processual originária. ${ }^{57}$

\subsubsection{Fundamentos vinculados à sentença}

Neste tópico analisaremos o cabimento da ação rescisória com base no art. 966 do CPC/2015, nas seguintes hipóteses: a) do inciso IV, ofensa à coisa julgada; e b) do inciso $\mathrm{V}$, violação manifesta à norma jurídica (de longe, o mais invocado nos tribunais). Vejamos então esses fundamentos.

\subsubsection{Ofensa à coisa julgada}

Primeiramente, esclareça-se que a coisa julgada a que se refere este tópico é a material, ou seja, aquela que atingiu o mérito da questão suscitada, e, em regra, ela não poderá ser desfeita. Rememore-se que não há sentido em falar, aqui, da ofensa à coisa julgada formal, pois esta não abre ensejo à ação rescisória, exceto nas hipóteses do art. $966, \mathbb{S} 2^{\circ}$, do CPC/2015. Registre-se também que, se utilizado novo processo para conseguir nova coisa julgada, essa segunda coisa julgada (que, em verdade, não existe no sistema) poderá ser rescindida com base no art. 966, IV. ${ }^{58}$ Ademais, não é requisito de admissibilidade da ação rescisória se a

57 "O herdeiro preterido ou prejudicado, que se pode valer da rescisória, é, pois, o que figurou no processo. Ao que não figurou, a sentença é res inter alios acta e, despida da autoridade da res iudicata; não impede que o terceiro discuta sua validade em simples ação ordinária em $1^{\circ}$ grau de jurisdição." (THEODORO JÚNIOR, Humberto. Partilha, p. 1179). No mesmo sentido: SANTOS, Ernane Fidélis dos. Comentários ao Código de Processo Civil. Rio de Janeiro: Forense, 1978, n. 343. p. 434.

58 A questão processual, por exemplo, sobre a intempestividade recursal, já foi objeto de ação rescisória por ofensa à coisa julgada e violação literal de lei. A esse respeito faz-se referência ao julgado do STJ: “Na hipótese dos autos, não houve a cogitada ofensa (...), porque, ao contrário do que sustentam os requerentes, o acórdão do TJDFT que concedera a segurança ainda não 
coisa julgada tenha ou não sido debatida no curso do processo que pretende ver a sentença ou acórdão rescindido; ainda que afastada a tese em preliminar, é admissível ressuscitar a ofensa à coisa julgada. ${ }^{59}$

Estabelecidas essas premissas, sob o fundamento do art. 966, IV, do CPC atual, é possível concluir que o pressuposto básico da ação rescisória, nesses moldes, é manifestado na existência de duas coisas julgadas sobre a mesma relação jurídico-material.

Não obstante, poder-se-ia pensar que essa segunda coisa julgada não existiria; assim, deveria ser atacada com a ação declaratória de inexistência, e não a ação rescisória, logo, não estaria sujeita ao prazo de dois anos do trânsito em julgado para o ajuizamento da ação rescisória. A tal inexistência estaria fulcrada na falta de interesse de agir (falta de condição de ação - art. 485, VI, do CPC/2015) e em pressuposto negativo de existência (coisa julgada - art. 485, V, do CPC/2015). ${ }^{60}$

Assim, se inexistente a segunda coisa julgada, sem sombra de dúvida, decorreria que a primeira coisa julgada deve prevalecer pelos seguintes argumentos: primeiro, porque o processo da segunda coisa julgada deveria ter sido julgado extinto, sem julgamento do mérito; segundo, porque nem mesmo a lei pode prejudicar a coisa julgada, uma vez que possuiria caráter constitucional de direito adquirido (art. $\left.5^{\circ}, \mathrm{XXXVI,CF}\right) .{ }^{61}$

havia transitado em julgado quando a União Federal interpôs o recurso especial. (...) Ação rescisória improcedente”. (AR 4.545/DF, Rel. Ministro Humberto Martins, $1^{a}$ Seção, julgado em 28.03.2012, DJe 03.04.2012).

59 SOUZA, Bernardo Pimentel. Introdução aos recursos cíveis e à rescisória. 6. ed. São Paulo: Saraiva, 2009. p. 215.

${ }^{60}$ Nesse sentido, sustentam Teresa Arruda Alvim Wambier e José Miguel Garcia Medina: “(...) aquele que pleiteia reexame de pedido já decido pelo Judiciário, intenta a segunda ação apesar da falta de interesse de agir. Assim, é, o autor, carente de ação. Só que, em nosso entender, está-se, aqui, diante de um caso de inexistência jurídica e não de nulidade. Conforme temos sustentado, não estando preenchidas as condições da ação, não pode o juiz decidir o mérito, sob pena de, fazendo-o, estar proferindo sentença juridicamente inexistente". (WAMBIER, Teresa Arruda Alvim; MEDINA, José Miguel Garcia. O dogma da coisa julgada, p. 38).

61 “... se decorrido o prazo de dois anos para propor a ação rescisória, deve prevalecer a primeira sentença. (...) Não se monstra coerente a prevalência da sentença proferida depois, já que veio ela em ofensa aos ditames legais. Torna-se nula a segunda sentença, posto que vedada por lei, podendo o juízo, de ofício, em qualquer ato de processo, não reconhecê-la, e lançar o veredicto da ineficácia." (RIZZARDO, Arnaldo. Limitações do trânsito em julgado e desconstituição da sentença, p. 308). 
A contrario sensu, considerar inexistente a segunda coisa julgada é mais que mitigar os efeitos e a extensão do art. 966, IV, do CPC/2015, é tornar o texto letra morta ${ }^{62} \mathrm{Em}$ atenção a isso, a melhor interpretação aponta que a falta da propositura da ação rescisória acarretará a convalidação dessa segunda coisa julgada. ${ }^{63}$ Note-se que, no estudo da revogação, lei posterior revoga a anterior, e, portanto, pelo mesmo raciocínio, a segunda coisa julgada efetivamente revoga a primeira ${ }^{64}$ não há como fugir dessa realidade. ${ }^{65}$

\subsubsection{Violação manifesta à norma jurídica}

A lei comporta interpretações, e, no mais das vezes, essas interpretações, ainda que antagônicas, convivem normalmente no ordenamento jurídico. Por sua vez, as definições podem atingir um ponto máximo, permitindo sitiar o conceito e entender sua essência. O cabimento da ação rescisória por violação ${ }^{66}$ manifesta a norma jurídica (art. 966, V, do CPC/2015) é um desses conceitos que merecem uma definição clara, sob pena de malversar sua utilização. ${ }^{67}$

${ }^{62}$ Cf. DIDIER JR., Fredie; CUNHA, Leonardo José Carneiro da. Curso de direito processual civil. 10. ed. Salvador: JusPodivm, 2012. v. 3. p. 419. DINAMARCO, Cândido Rangel. Fundamentos do processo civil moderno, 3. ed., t. I. p. 1381. MOREIRA, José Carlos Barbosa. Comentários ao Código de Processo Civil, 2009, v. 5. p. 619; THEODORO JÚNIOR, Humberto. Curso de direito processual civil. 10. ed. Rio de Janeiro: Forense, 1993. p. 608.

63 YARSHELL, Flávio Luiz. Ação rescisória - juízo rescindente e rescisório, p. 318.

64 "A segunda deve prevalecer, não só como homenagem ao princípio da segurança jurídica, mas também pelo fato de que, se a sentença tem força de lei entre as partes (art. 468, CPC), lei posterior revoga a anterior, não obstante a segunda lei pudesse ter sido rescindida; como não foi, fica imutável pela coisa julgada e, assim, deve prevalecer.” (DIDIER JR., Fredie; CUNHA, Leonardo José Carneiro da. Curso de direito processual civil, 10. ed., v. 3, p. 420). Corresponde o art. 468 do CPC/1973 o art. 503 CPC/2015.

65 Vale ressalvar que no caso em que ocorram duas coisas julgadas favoráveis à mesma parte, uma completando a outra, não caberá a ação rescisória iniciada pela parte vencedora, haja vista a falta de interesse de agir. (RODRIGUES, Marcelo Abelha. Manual de direito processual civil. 5. ed. rev., atual. e ampl. São Paulo: RT, 2010. p. 564).

${ }^{66}$ Sobre a eficácia da lei e a sanção por infringência, confira-se: "la legge riuscirebbe soventi volte inefficace, se potesse dai cittadini essere impugnemente violata; di qui pertanto la necesità che essa sia munita di una sanzione, ossia di mezzi atti a garantirne l'osservanza". (BALLERINI, Giuseppe Velio. Istituzioni di diritto e di procedura civile: secundo I Codici Italini. Torino: Camila e Bertolero, 1874. p. 33).

67 Aliás, a beleza do direito está especialmente na diversidade de soluções que uma questão possa alcançar. "A jurisprudência desta Corte é no sentido de que, para que a ação rescisória seja acolhida por ofensa a dispositivo de lei (CPC, art. 485, V), é preciso que a norma legal tida 
Com a edição do CPC/2015, substituiu-se o termo "literal disposição de lei" por "manifestamente norma jurídica". Antes do CPC atual, durante a vigência do Código de Processo Civil de 1973, a doutrina já se posicionava pelo amplo sentido que o termo "lei" possuía, abrangendo a norma jurídica geral e abstrata. "O vocábulo 'lei', no dispositivo em exame, compreende obviamente a própria Constituição e ainda qualquer espécie legislativa nela prevista (CF, art. 59). Mais ainda: abrange as normas de direito estadual, municipal e estrangeiro. Há quem chegue a cogitar que os regulamentos administrativos estariam amparados pelo termo. O alcance da expressão é amplíssimo. Não faria sentido interpretação que excluísse de tal hipótese a ofensa à norma constitucional, precisamente a afronta mais grave à ordem jurídica." 68

“Não estão na 'letra da lei' os limites do ordenamento jurídico; e nem só do não atendimento à literalidade do texto, muito pelo contrário, existe violação de norma jurídica. (...) na atual quadra da teoria do direito é praticamente assente que tanto as regras jurídicas quanto os princípios constituem espécies de normas jurídicas, e que mesmo os princípios implícitos são dotados de positivação. Ao mesmo tempo, é indubitável que a norma jurídica não se confunde com o texto da lei, sendo, antes, o resultado da atribuição de sentido ao texto." 69

Lei, no dispositivo do art. 485, V, do antigo CPC, compreendia "à evidência, a Constituição, a lei complementar, ordinária ou delegada, a medida provisória, o decreto legislativo, a resolução (Carta da República, art. 59), o decreto emanado do Executivo, o ato normativo baixado por órgão do Poder Judiciário (v.g., regimento interno: Constituição Federal, art. 96, n. I, letra $a$ ). Inexiste qualquer diferença, a esse respeito, entre normas jurídicas editadas pela União, por Estado-membro ou por Município. Também a violação de norma jurídica estrangeira torna rescindível a sentença, na hipótese de ter-se de aplicar à espécie o direito do

como ofendida tenha sofrido violação em sua literalidade, de sorte que, se o acórdão rescindendo elege uma dentre as interpretações cabíveis, ainda que não seja a melhor, a ação rescisória não merece êxito. Precedentes. 2. Agravo regimental não provido.” (STJ - AgRg no AREsp 139.406/MG, Rel. Ministro Benedito Gonçalves, $1^{\text {a }}$ Turma, julgado em 05.06.2012, DJe 12.06.2012). Corresponde ao art. 485, inciso V, do CPC/1973 o art. 966 , inciso V, do CPC/2015.

68 TALAMINI, Eduardo. Coisa julgada e sua revisão, p. 158.

69 MAZZEI, Rodrigo; GONÇALVES, Tiago Figueiredo. Primeiras linhas sobre a disciplina da ação rescisória no CPC/2015. In: DIDIER JR., Fredie (coord.); MACÊDO, Lucas Buril de; PEIXOTO, Ravi; FREIRE, Alexandre. Novo CPC - doutrina selecionada, v. 6: processo nos tribunais e meios de impugnação às decisões judiciais, p. 253. 
outro país" ${ }^{70}$ Ainda, a violação de literal disposição de lei pode ser evidenciada pela ausência de apreciação de nulidade contratual. ${ }^{71}$

Há violação de lei quando o julgador: a) negar validade a uma lei, embora seja válida; b) dar validade a uma lei, muito embora não seja válida; c) negar vigência a uma lei, embora vigente; d) atribuir vigência a uma lei que ainda não vige, ou seja, que não integre o sistema positivo que regula o caso; ou, por derradeiro, e) fundamentar a decisão em uma norma que não se adéque ao caso. ${ }^{72}$ "Todos esses referenciais do conceito são facilmente compreendidos, e não é aí, em regra, que ocorre a violação de literal disposição de lei. Esta tem lugar onde a interpretação que se confere à lei é tão absurda que a lei, em lugar de ser aplicada, é desfigurada no seu sentido.”73

Entendemos por bem manter a explicação do que a doutrina já considerava do termo "lei" e em quais hipóteses havia a sua violação, uma vez que, considerando que a norma jurídica, no amplo sentido que o legislador pretendeu incluir no inciso V do art. 966 do CPC/2015, compreende também a letra da lei, continua-se aplicando o disposto nos dois parágrafos acima mesmo após a vigência do novo CPC.

Neste passo, "as normas jurídicas não são os textos de lei, nem o conjunto deles, e sim os sentidos construídos a partir da conformação constitucional, da interpretação sistemática dos textos legais, dos valores dominantes e da interação com os fatos. Os dispositivos de lei constituem-se no objeto da atividade hermenêutica, e as normas, no seu resultado". ${ }^{74}$

Admite-se uma gama de métodos hermenêuticos para se afinar com a melhor interpretação da norma jurídica no âmbito da ação rescisória. São os méto-

70 MOREIRA, José Carlos Barbosa. Comentários ao Código de Processo Civil. 16. ed. Rio de Janeiro: Forense, 2012. v. V. p. 129.

${ }^{71}$ BARIONI, Rodrigo Otávio. Ação rescisória: violação de literal disposição de lei por não se haver apreciado alegação superveniente de nulidade de contrato. Revista de Processo, São Paulo: RT, v. 37, n. 204, p. 319-348, fev. 2012. p. 325.

72 "Analisado o texto no conjunto do ordenamento a partir das circunstâncias do caso, há de existir sempre uma norma que se afigura a mais adequada. Se a decisão, contudo, extrai para o caso uma norma que destoa flagrantemente daquela que se reputa a mais adequada, viola manifestamente norma jurídica para fins de rescindibilidade" (MAZZEI, Rodrigo; GONÇALVES, Tiago Figueiredo. Primeiras linhas sobre a disciplina da ação rescisória no CPC/2015. In: DIDIER JR., Fredie (coord.); MACÊDO, Lucas Buril de; PEIXOTO, Ravi; FREIRE, Alexandre. Novo CPC - doutrina selecionada, v. 6: processo nos tribunais e meios de impugnação às decisões judiciais, p. 253).

${ }^{73}$ RIZZI, Luiz Sérgio de Souza. Da ação rescisória. Revista de Processo, v. 26. p. 188.

74 ALVIM, Angélica Arruda (coord.) [et al.]. Comentários ao Código de Processo Civil, p. 1106. 
dos: gramatical, lógico, sistemático, histórico, sociológico, evolutivo, teleológico e axiológico, podendo-se recorrer até mesmo ao direito comparado.

Veda-se, porém, ao intérprete produzir resultado que possa restringir ou ampliar o direito ao acesso à via rescisória. Veda-se também a alegação da ofensa à norma jurídica quando não haja uma referência escrita na decisão rescindenda aquela que possa aquilatar a materialidade do vício,$-{ }^{75}$ pois a violação a norma jurídica deve estar absurdamente demonstrada na análise dos autos, fatos e direito, em cotejo com a decisão de mérito.

O limite interpretativo estará no próprio sentido que comportar a norma jurídica, podendo o hermeneuta se utilizar dos métodos interpretativos, de modo singular ou em conjunto (combinados entre si), na busca da interpretação especificadora ou declarativa.

A decisão meritória com aplicação errônea da regra jurídica ou que tenha passado ao largo dela, sem tocá-la, afastando-a por omissão, pode gerar o caso de ação rescisória com fundamento no art. 966, inciso V, do CPC/2015.

O termo "manifestamente" "relaciona-se à interpretação (construção do sentido) consagrada pelos Tribunais Superiores (STF e STJ) - que têm a função de uniformizar (de dar a última ratio), respectivamente, a interpretação da Constituição e da legislação infraconstitucional federal (o mesmo se aplica aos Tribunais de Justiça quanto ao direito local)" ${ }^{76} \mathrm{E}$ a ofensa manifesta "pode ser à norma material (error in judicando) ou à norma processual (error in procedendo), o que, em regra, terá influência decisiva sobre o juízo rescisório. Se o erro foi de julgamento, será, em princípio, possível que o órgão julgador já profira a nova decisão, em substituição à anterior; mas se o erro for processual, haverá necessidade de que o processo originário seja retomado no ponto em que foi perpetrado o erro capaz de influir no julgamento". ${ }^{77}$

A violação manifesta da norma jurídica está presente nos casos de sentença ultra ou extra petita, porque caracterizam ofensa aos arts. 141 e 492 do CPC/2015. O que se verifica nesses casos é que a correta aplicação da lei acaba por alterar o resultado do julgamento de mérito já transitado em julgado, e, assim, haverá o cabimento da ação rescisória para extirpar tal vício.

\footnotetext{
75 "Já se decidiu, no entanto, no sentido de que, não tendo sido a questão enfrentada na decisão rescindenda, a ação rescisória é inadmissível (STJ, AR 2.810/SP, 3. ${ }^{a}$ Seção, j. 12.12.2007, Rel. Min. Laurita Vaz)". (MEDINA, José Miguel Garcia. Novo Código de Processo Civil comentado, p. 1382).

76 ALVIM, Angélica Arruda (coord.) [et al.]. Comentários ao Código de Processo Civil, p. 1105.

77 GONÇALVES, Marcus Vinicius Rios. Direito processual civil esquematizado, p. 562.
} 
A Súmula 343 do STF permite uma distinção de sua aplicação no campo infraconstitucional em confronto com casos de aplicação da ação rescisória proposta em face de dispositivo da Constituição Federal. ${ }^{78} \mathrm{O}$ sentido da citada súmula é para negar o cabimento, ${ }^{79}$ contudo, nos casos em que haja pronunciamento do Supremo Tribunal Federal, a súmula assume aspecto positivo, ou seja, a existência de um precedente no STF abre o cabimento da ação rescisória pelo art. 966, V, do CPC/2015.

78 Nessa esteira, no Supremo Tribunal Federal uniformizou-se a jurisprudência no sentido de que "não cabe ação rescisória por ofensa a literal disposição de lei, quando a decisão rescindenda se tiver baseado em texto legal de interpretação controvertida nos tribunais" (Súmula 343). Data venia, na prática, a própria Súmula 343 admite algumas acepções, senão vejamos: a) uma parcela dos precedentes se inclina no sentido de superar a vedação da matéria ser controvertida nos tribunais, entendendo cabível a ação rescisória quando a decisão rescindenda tiver fundamento em matéria constitucional (STJ - AR 705/MG; Rel. Ministro Francisco Falcão, rev. Ministro Franciulli Netto, $1^{a}$ Seção, julgado em 27.02.2002; e STJ - REsp 130.234/DF, Rel. Ministro João Otávio de Noronha, $2^{\text {a }}$ Turma, julgado em 02.12.2004); b) outra parcela dos precedentes aplica, com toda rigidez possível, o texto literal da Súmula 343 (STJ, AgRg na AR 3.192/PR, Rel. Ministro Castro Meira, 1 ${ }^{a}$ Seção, julgado em 10.11.2004; e STJ - REsp 621.662/ DF, Rel. Ministro Eliana Calmon, $2^{\text {a }}$ Turma, julgado em 06.05.2004); c) outro entendimento encontrado nos precedentes é pelo afastamento da Súmula 343 no caso de matéria sumulada pelo Superior Tribunal de Justiça, e o juízo ter julgado contrariamente à própria Súmula do STJ - nesse caso haverá cabimento da ação rescisória (STJ - REsp 669.461/RS, Rel. Ministro Franciulli Netto, $2^{\text {a }}$ Turma, julgado em 04.11.2004; e STJ - REsp 427.814/MG, Rel. Ministro Eliana Calmon, $2^{\text {a }}$ Turma, julgado por maioria de votos em 02.09.2004); d) quando a rescisória é fundamentada em erro de fato, também se registram casos em que houve cabimento da rescisória (STJ - AR 836/RS, Rel. Ministro Francisco Falcão, rev. Ministro Franciulli Netto, $1^{a}$ Seção, julgado em 05.2002; e STJ - AR 1.381/DF, Rel. Ministro Francisco Peçanha Martins; rev. Ministro Humberto Gomes de Barros, $1^{a}$ Seção, julgado em 13.11.2002); e) há, por fim, precedente em que se acolheu a ação rescisória fundada em julgado desconexo com o pedido, por violação literal do art. 460 do CPC (STJ - AR 896/RS, Rel. Ministro Francisco Falcão, $1^{\text {a }}$ Seção, julgado em 25.08.2004).

79 Há, contudo, quem critique este posicionamento: “A posição do STJ quando à observância do Enunciado 343 da Súmula do STF finda por enfraquecer suas decisões, ou melhor, as decisões do intérprete último e guardião da legislação infraconstitucional federal. De acordo com a jurisprudência dominante do STJ, pouco importa se a decisão, à época da formação da coisa julgada, estava em consonância ou não com sua jurisprudência, pois basta haver divergência nas instâncias ordinárias para se afastar o cabimento da ação rescisória. O Enunciado 343 da Súmula do STF é incompatível com a atual e elevada função do STJ de intérprete definitivo e guardião da legislação infraconstitucional federal, que inclusive, passará a produzir diversos precedentes com eficácia vinculante (art. 927, III, IV e V, CPC/2015)”. (ALVIM, Angélica Arruda (coord.) [et al.]. Comentários ao Código de Processo Civil, p. 1106). 
Em decorrência disso, verifica-se que é cabível o ajuizamento de ação rescisória no Supremo Tribunal Federal, competente para processar e julgar originariamente a ação rescisória de seus julgados (art. 102, I, j, da CF), sendo exemplo o caso em que o Ministro Relator do acórdão proferido pelo Supremo Tribunal Federal estava impedido ${ }^{80}$ por participação em julgamento anterior no mesmo processo, em sede de primeira ou segunda instância, ou a hipótese em que a Turma não conhece recurso extraordinário por não ter o acórdão recorrido contrariado dispositivo constitucional e, após, sobrevinda, pelo Tribunal Pleno, decisão meritória em caso semelhante.

\subsection{Vedação do cabimento com fundamento na violação manifesta à norma jurídica, diante de interpretação controvertida nos tribunais}

Existem situações que admitem certa flexibilidade na solução do conflito. Ainda, há casos em que a matéria contida no texto normativo não se encontra pacificada nas decisões precedentes e na doutrina, razão pela qual a interpretação, assim tida como controversa, via de regra, não enseja o cabimento da ação rescisória. Frise-se que a interpretação controversa, para essa finalidade, é entendida como aquela focada em decisões precedentes conflitantes sobre a égide do mesmo dispositivo legal - incide a Súmula 343 do STF -, não abrindo o cabimento da ação rescisória, ${ }^{81}$ salvo se matéria constitucional.

Não estamos aqui a falar de meia dúzia de decisões equivocadas e absurdas, que contrariam diretamente o sentido da lei aplicada à espécie. Seria uma

${ }^{80}$ Tal tese de impedimento não pode ser oposta em ação rescisória, quando se tratar de controle concentrado. Veja-se o trecho da ementa em destaque: "Os institutos do impedimento e da suspeição restringem-se ao plano dos processos subjetivos (em cujo âmbito discutem-se situações individuais e interesses concretos), não se estendendo nem se aplicando, ordinariamente, ao processo de fiscalização concentrada de constitucionalidade, que se define como típico processo de caráter objetivo destinado a viabilizar o julgamento, não de uma situação concreta, mas da constitucionalidade (ou não), 'in abstracto', de determinado ato normativo editado pelo Poder Público”. Não obstante, "Revela-se viável, no entanto, a possibilidade de qualquer Ministro do Supremo Tribunal Federal invocar razões de foro íntimo (CPC, art. 135, parágrafo único) como fundamento legítimo autorizador de seu afastamento e consequente não participação, inclusive como Relator da causa, no exame e julgamento de processo de fiscalização abstrata de constitucionalidade". (STF - ADI 3.345, Rel. Ministro Celso de Mello, Tribunal Pleno, julgado em 25.08.2005, DJe-154 divulgado em 19.08.2010 e publicado em 20.08.2010; RTJ 217/162).

81 "Não cabe ação rescisória por ofensa a literal dispositivo de lei, quando a decisão rescindenda se tiver baseado em texto de interpretação controvertida nos Tribunais." (Súmula 343 do STF). 
temeridade adotar-se esse tipo de interpretação, visivelmente exagerada, implicando restrição desmedida ao direito de ação. ${ }^{82}$

$\mathrm{Na}$ verdade, nesse caso, o sistema jurisdicional elege duas ou mais soluções possíveis e adequadas, ainda que conflitantes, quando comparadas em casos similares. ${ }^{83}$

As interpretações que convergem para a aplicação da Súmula 343 do STF não são unívocas. Essas soluções diversas convivem em harmonia no sistema ao tempo em que proferida a decisão, tendo em vista que os argumentos de uma e de outra corrente são igualmente válidos. Nessas hipóteses, não há como defender a fiscalização do ato decisório, nem mesmo por ação rescisória, pois se optou por uma das soluções possíveis. Vale dizer, não há ofensa manifesta a norma jurídica quando o acórdão rescindendo, dentre as interpretações cabíveis, elege uma delas. ${ }^{84}$

Sob a ótica da parte, é difícil aceitar essa realidade da coexistência, ao mesmo tempo, de decisões conflitantes, embora sejam casos distintos. Modos distintos de interpretação que produzem decisões diferentes para casos especialmente semelhantes. A inviabilidade da ação rescisória estará justamente na razoabilidade do pensamento divergente, contrário aos interesses do autor da ação rescisória, mas com respaldo em outras decisões, entendimento este prevalecente na decisão rescindenda. A má interpretação, que autorizaria a rescisão pela violação literal de disposição de lei, fica afastada em face de outra interpre-

82 "Daí a enxergar em qualquer divergência obstáculo irremovível à rescisão vai considerável distância: não parece razoável afastar a incidência do art. 485, n. V, só porque dois ou três acórdãos infelizes, ao arrepio do entendimento preponderante, hajam adotado interpretação absurda, manifestamente contrária ao sentido da norma." (MOREIRA, José Carlos Barbosa. Comentários ao Código de Processo Civil, 16. ed., v. V, p. 129). Corresponde ao art. 485, inciso V, do CPC/1973 o art. 966, inciso V, do CPC/2015.

83 Conforme a Súmula 134 do antigo Tribunal Federal de Recursos, "não cabe ação rescisória por violação de literal disposição de lei se, ao tempo em que foi prolatada a sentença rescindenda, a interpretação era controvertida nos Tribunais, embora posteriormente se tenha fixado favoravelmente à pretensão do autor". Há, ainda, a Súmula 3 do antigo Primeiro Tribunal de Alçada de São Paulo, que reza: "descabe o ajuizamento de ação rescisória quando fundado em nova adoção de interpretação do texto legal".

84 "Inocorrência de violação literal de dispositivo legal pelo acórdão rescindendo que conferiu interpretação razoável à legislação processual vigente. (...) Não caracterização do erro de fato quando a controvérsia suscitada tenha sido objeto de debate e pronunciamento nas instâncias ordinárias e nesta Corte Superior. (...) Ação rescisória julgada improcedente.” (STJ - AR 3.369/ MT, Rel. Ministro Paulo de Tarso Sanseverino, 2a Seção, julgado em 09.05.2012, DJe 15.05.2012). 
tação igualmente adotada por nossos Tribunais, porque restará inexistente a dita má interpretação. ${ }^{85}$

Não se deve confundir esse pensamento com a concorrência de outra interpretação que não venha mais sendo adotada pelos Tribunais, confirmando-se interpretação historicamente ultrapassada ao tempo da decisão rescindenda.

Não há falar-se em ofensa da interpretação que não destoa do sentido da norma jurídica. ${ }^{86} \mathrm{~A}$ não concordância com uma das correntes se dá no plano da discricionariedade, que, por sua vez, não pode ser um critério jurisdicional, pois este se pauta pela estrita legalidade, o que restará atendido in totum em casos como tais. O sistema convive com soluções diversas, e, justamente por ser matéria controversa, se admitida a ação rescisória, isso contribuiria para um efeito indesejado por todos: a eternização do conflito, com interposição de ações rescisórias infindáveis. Mesmo após a pacificação do tema, se ao tempo da sentença ou acórdão pendia a situação controvertida, não haverá cabimento da ação rescisória, não se configurando a violação manifesta de norma jurídica para esse efeito.

\subsubsection{Fundamentos vinculados às provas}

Vejamos então a análise dos fundamentos rescisórios ligados às provas, com base no art. 966 do CPC/2015: a) prova falsa; e b) prova nova.

\subsubsection{Prova falsa}

Há cabimento da ação rescisória da sentença proferida com base em prova falsa, cuja falsidade apurou-se em processo criminal ou possa ser provada na própria ação rescisória, conforme preceitua o art. 966, VI, do CPC/2015. ${ }^{87}$

85 RIZZI, Luiz Sérgio de Souza. Da ação rescisória. Revista de Processo, v. 26. p. 189.

${ }^{86}$ Por outro lado, “não há ofensa mais grave à lei do que aplicá-la a um quadro fático em que esta não se encaixa, que a esta não corresponde!!!”. (ALVIM NETTO, José Manoel de Arruda; ALVIM, Teresa Arruda. Qualificação jurídica do fato feita equivocadamente dá azo à rescisória - art. 485, V. Revista de Processo, São Paulo: RT, v. 76, out. 1994. p. 164; tb. Doutrinas Essenciais de Processo Civil, v. 7, out. 2011. p. 1273).

87 “Como acentuado, no Título I, n. 4, retro, entre os casos de cabimento da ação rescisória, nele elencados, o Código de 1939, em seu art. 798, n. II, estabelecia a rescindibilidade da sentença, 'quando o seu principal fundamento for prova declarada falsa em juízo criminal, ou de falsidade inequivocamente apurada na própria ação rescisória'. Repetindo tal preceituação, cujo teor, assim como transcrito, fora devido ao disposto na Lei n. 70, de 20.8.1947, a legislação processual civil codificada em vigor expressa, no art. 485, n. VI, ser rescindível a sentença de mérito, transitada em julgado, quando 'se fundar em prova, cuja falsidade tenha sido apurada em 
Não se descarta a prova da falsidade documental no próprio juízo cível, por exemplo, em ação declaratória autônoma (art. 19, II, do CPC/2015). Na verdade, a decisão de mérito pode estar viciada porque exarada com suporte em prova falsa e, em assim sendo, sua rescindibilidade será corolário de justiça.

Note-se que a falsidade no juízo cível se circunscreve a documento, não a outras modalidades probatórias, porque o processo civil somente contempla a previsão da declaração de falsidade documental. A procedência da declaração incidental de falsidade (arts. 503 e 1.054 do CPC/2015) tem aptidão para produzir a coisa julgada material, e, quando o fundamento da ação rescisória se pautar neste tipo de prova, a rescisão se projeta como quase certa, em vista da qualidade da prova. É efeito direto da causa, da motivação robusta no sentido da procedência rescindente.

Aliás, essa relação de causalidade deve se refletir entre a prova e a sentença, pois o cabimento da ação rescisória na espécie está amparado na situação de que a inexistência da prova que se revelou falsa levaria o julgador a outro resultado da sentença ${ }^{88} \mathrm{~A}$ indiferença da existência da prova falsa no resultado da sentença é caso que afasta o cabimento da ação rescisória.

Nessa esteira, a demonstração da prova falsa deve ser capaz de alterar o julgamento. $\mathrm{O}$ autor deve provar não só a prova falsa, mas também o nexo de causalidade entre a prova falsa e o resultado do julgamento de mérito. Podendo ser mantida a mesma decisão por outro fundamento, não haverá o cabimento rescisório com base na falsidade da prova. Quando a prova técnica tenha sido

processo criminal, ou seja, provada na própria ação rescisória'. Como fácil fica de perceber, evitou o legislador de 1973, com acuidade, a referência, anteriormente constante do texto legal, a que a prova falsa fosse o principal fundamento do ato decisório rescindendo. E fê-lo muito bem, mesmo porque, como anota a doutrina, processual, referendando o entendimento de Luís Eulálio de Bueno Vidigal, nos seus Comentários ao Código de Processo Civil, São Paulo, 1974, v. VI, p. 128, n. 4, não há, realmente, possibilidade de estabelecer-se gradação entre os fundamentos de fato da sentença: todos os fatos alegados e discutidos e, afinal, nesta examinados, devem somar-se, com efeito, em prol da formação do convencimento do juiz, e de tal modo, que se faça por não conferir maior destaque a qualquer deles, tendo-o como principal fundamento relativamente aos demais. Ora, partindo dessa precisa observação, pode-se afirmar que a sentença se torna suscetível de rescindibilidade quando, lastreada em prova falsa, compuser o litígio diferentemente do que o faria, não fosse o equívoco resultante da falsidade." (TUCCI, Rogério Lauria. Ação rescisória fundada em prova falsa. Doutrinas Essenciais de Processo Civil, São Paulo: RT, v. 7, out./2011. p. 1075). Corresponde ao art. 485, inciso VI, do CPC/1973 o art. 966, inciso VI, do CPC/2015.

88 MEDINA, José Miguel Garcia. Novo Código de Processo Civil comentado, p. 1387. 
demonstrada falsa, poderá o tribunal determinar seja produzida nova prova para balizar um julgamento íntegro (arts. 972 e 973 do CPC/2015). ${ }^{89}$

Mas o que vem a ser prova falsa? "Falsa é a prova em que há mistificação, engano, afastamento da verdade, adulteração. No exame pericial, um erro técnico não constitui prova falsa, porque não há aí a maquinação, não há adulteração. Se houver, por sem dúvida, será fundamento para se enquadrar no conceito de prova falsa." ${ }^{90}$ Nesse caso, será necessária a demonstração dessa mistificação ou adulteração, produzida fora do âmbito do juízo técnico peculiar à elaboração da perícia.

Quando a prova for obtida por meio ilícito, a sentença padecerá de nulidade, porém não será o caso da ação rescisória fundada pelo art. 966, VI, do CPC/2015, e sim de caber invocar a hipótese do inciso III ou V do mesmo artigo, pois não se trata de prova falsa. ${ }^{91}$ Ademais, tanto a falsidade material ${ }^{92}$, que consiste em eventuais vícios na forma e em aspectos exteriores da formação do documento, como a ideológica, assim entendida aquela que respeita aos vícios do consentimento ou sociais do ato jurídico, não permitem a instalação do

${ }^{89}$ Veja-se: “Ação rescisória. Responsabilidade civil do Estado. Ato judicial. Inviável se faz a ação rescisória para novo julgamento da causa ou para rediscutir as questões de direito controvertidas. Súmula 343. Não cabe, em ação rescisória, reexaminar a matéria de fato apreciada no acórdão. Se foi equivocado o exame dessa prova, ou não, a ação rescisória não é o meio adequado a enfrentar esse tema, sendo certo que não se sustenta, na demanda rescisória, haja o aresto rescindendo se fundamentado em prova falsa. Ação rescisória improcedente”. (STF - AR 973, Rel. Ministro Néri da Silveira, Tribunal Pleno, julgado em 19.04.1991, DJ 30.04.1992, p. 5723, RTJ 141-02/425).

${ }^{90}$ RIZZI, Luiz Sérgio de Souza. Da ação rescisória. Revista de Processo, v. 26. p. 189.

91 DIDIER JR., Fredie; CUNHA, Leonardo José Carneiro da. Curso de direito processual civil. 10. ed., v. 3, n. 7.9, p. 432.

92 Acerca do mesmo tema, ensina Antônio Carlos de Araújo Cintra: "O incidente de falsidade se destina a apurar apenas a falsidade material do documento. Realmente, como salienta Pontes de Miranda, 'o documento falso não existe como documento verdadeiro'. A falsidade material está no plano da admissibilidade do documento como prova, de modo que, verificada a sua falsidade material, o documento sequer é apreciado no seu conteúdo. Sendo, entretanto, materialmente genuíno, o documento escrito é examinado por seu conteúdo declaratório de vontade ou de ciência. Na declaração de vontade, o contraste entre a vontade declarada e a vontade real é uma simulação, não uma falsidade documental: a seu respeito se fala em validade ou invalidade, mas não em autenticidade ou falsidade. E a declaração de ciência, por sua vez, pode ser mendaz, quando não se acomoda à realidade, mas tampouco constitui falsidade documental suscetível de apuração por via do incidente em exame". (CINTRA, Antônio Carlos de Araújo. Comentários ao Código de Processo Civil. Rio de Janeiro: Forense, 2000. v. IV. p. 132-133). 
incidente, mas a anulação do ato jurídico nas formas do art. 147, II, do CC ou, por meio de reconvenção, autorizam o ajuizamento da ação rescisória com base no art. 966, VI, do CPC/2015.

Não é requisito obrigatório da rescisória a arguição da falsidade no curso do processo. ${ }^{93}$ Porém, caso tenha sido apurada em incidente processual, julgada por resolução de mérito, acarretará a vinculação da autoridade da coisa julgada, que a rescisória não poderá afrontar. ${ }^{94}$

\subsubsection{Prova nova}

A prova nova, aquela preexistente ao tempo da decisão rescindenda, mas caracterizada pela sua obtenção ou disponibilidade após a sentença ou acórdão, também pode abrir cabimento à ação rescisória, desde que a parte beneficiada não tenha se utilizado atempadamente da prova, porque essa hipótese lhe era impossível ou porque sua existência era ignorada ao tempo da sentença. ${ }^{95}$ Nessa

93 MAZZEI, Rodrigo; GONÇALVES, Tiago Figueiredo. Primeiras linhas sobre a disciplina da ação rescisória no CPC/2015. In: DIDIER JR., Fredie (coord.); MACÊDO, Lucas Buril de; PEIXOTO, Ravi; FREIRE, Alexandre. Novo CPC - doutrina selecionada, v. 6: processo nos tribunais e meios de impugnação às decisões judiciais, p. 254.

${ }^{94}$ Confira-se: BARIONI, Rodrigo Otávio. Ação rescisória e recursos para os tribunais superiores, p. 116-117. RIZZI, Luiz Sérgio de Souza. Ação rescisória, p. 152-153; MOREIRA, José Carlos Barbosa. Comentários ao Código de Processo Civil, 2009, v. 5, p. 136.

95 Sobre a questão, confira-se o parecer ministerial, da lavra do Dr. Miguel Bandeira Pereira, que restou transcrito no voto condutor da decisão em referência, senão vejamos: “(...) Como se sabe, não é qualquer documento novo, no sentido comum, que autoriza o exercício da ação rescisória. Para os efeitos do artigo 485, inciso VII, do Código de Processo Civil, documento novo é aquele que já existia ao tempo em que foi proferida a sentença rescindenda, mas cuja existência o autor ignorava, ou de que não pôde fazer uso. O documento novo deve, ainda, ser de tal ordem e alcance que, sozinho, favoreça o autor da rescisória, sob pena de não ser idôneo para o decreto de rescisão. É, ainda, requisito para o êxito dessa ação que o documento juntado na inicial não estivesse ao alcance da parte no curso da ação onde proferido o julgado rescindendo. Dessa forma, seu aproveitamento, em sede de Rescisória, estaria condicionado à existência de contingências que tivessem obstaculizado sua utilização na demanda anterior. Sobre o tema, Sérgio Gilberto Porto refere que 'a obtenção de documento novo, ressalte-se, depende da ignorância da existência ou da impossibilidade de sua utilização, ao tempo da demanda originária. Nesse sentido, não pode, portanto, a parte haver concorrido, com sua negligência, para o não aproveitamento deste na demanda de então'. Dito isso, cabe observar que os atestados e exames juntados pelo autor às fls. 134 a 140 datam, alguns, de 2010 e 2011, fato que, por si só, os torna imprestáveis para fins de rescisão do julgado pelo fundamento alegado, uma vez que posteriores à decisão rescindenda (proferida em 
situação, bastará que a prova nova, por si só, seja capaz de assegurar decisão favorável à parte exibidora. É o que prescreve o art. 966, VII, do CPC/2015. ${ }^{96}$

O Código de Processo Civil de 2015 “fala em prova nova e não mais em documento novo. Isso quer dizer que não só a prova documental nova dá azo à ação rescisória". ${ }^{97}$ Ampliou-se, assim, o cabimento da ação rescisória fundada no inc. VII do art. 966.

Prova nova "não é aquela cuja constituição operou-se após a decisão transitada em julgado, mas cuja existência, embora anterior, era ignorada pelo autor da ação rescisória, ou de que ele não pôde fazer uso, por circunstâncias alheias à sua

27.05.2009). E quanto àqueles documentos anteriores à prolação do julgado (fls. 136 e 139), a par de não demonstrarem a alegada invalidez, poderiam perfeitamente ter sido juntados ao feito originário, uma vez que, já à época, se encontravam ao alcance do demandante". (TJRS - AR 70.043.373.927/RS, Terceiro Grupo Cível, Rel. Des. Romeu Marques Ribeiro Filho, julgado em 23.03.2012). Corresponde ao art. 485, inciso VII, do CPC/1973 o art. 966, inciso VII, do CPC/2015. Ressalte-se que, no atual CPC, substituiu-se o termo "documento novo" por "prova nova".

96 A consagração desse dispositivo vem com larga utilização em nossos tribunais, distribuindo a justiça em causas que outrora estavam fadadas ao injusto, por ausência de "utilização oportuna” do documento. Assim, pode-se alargar a definição de documento novo com nítido propósito de se alcançar a justiça. Confira-se a ementa: "Previdenciário e processual civil. Aposentadoria rural por idade. Ação rescisória. Documento novo. Certidão de óbito do marido da autora. Qualificação como lavrador. Início de prova material configurado. Documento preexistente à propositura da ação. Irrelevância. Solução pro misero. Súmula n. 149 do STJ afastada. Pedido procedente. 1. A jurisprudência dominante desta Corte Superior se orienta no sentido de que é possível o acolhimento da ação rescisória, ante a juntada de documento novo, nas hipóteses como a dos autos, em que se pleiteia aposentadoria rural por idade, quando apresentada, além de outras provas, certidões, como a de casamento, nascimento ou óbito, em que se atesta o ofício de trabalhador rural do marido da demandante. 2. A Terceira Seção desta Corte Superior, levando em conta as condições desiguais pelas quais passam os trabalhadores rurais, tem adotado a solução pro misero, entendendo irrelevante o fato de o documento apresentado ser preexistente à propositura da ação. Dessa forma, o documento juntado aos autos é hábil à rescisão do julgado com base no artigo 485, inciso VII, do Código de Processo Civil, afastando-se a incidência da Súmula 149 do STJ. Precedentes. 3. Pedido julgado procedente com o restabelecimento do acórdão do Tribunal Regional Federal da $3^{a}$ Região". (STJ - AR 2.197/MS, Rel. Ministro Vasco Della Giustina (Desembargador Convocado do TJRS), $3^{\text {a }}$ Seção, julgado em 28.03.2012, DJe 13.04.2012). Importante pontuar que, com a entrada em vigência do CPC de 2015, fala-se em prova nova e não mais em documento novo.

${ }^{97}$ MARINONI, Luiz Guilherme; ARENHART, Sérgio Cruz; MITIDIERO, Daniel. Novo Código de Processo Civil comentado, p. 1024. 
vontade. Se deixou de ser apresentada por culpa da parte, que agiu com desídia ou negligência, porque ela era acessível, não cabe a rescisória". ${ }^{98}$

É necessário que a prova nova trazida à baila seja suficiente para a alteração da decisão rescindenda, ou seja, na demanda rescisória, tenha um resultado favorável..$^{99}$

A prova confeccionada ou constituída após finalizado o processo rescindendo, uma vez findo o seu desiderato cognitivo, não se revestirá da necessária novidade para efeitos rescisórios. A prova nova para a ação rescisória não poderá ser constituída em um fato novo, produzido após a decisão rescindenda, quiçá após o trânsito em julgado material. Portanto, até mesmo o fato novo afasta o cabimento da ação rescisória.

O fato que autoriza a ação rescisória é aquele que foi alegado tempestivamente no processo em que proferida a decisão rescindenda, porém em que restou ausente a respectiva prova. A novidade da prova afasta a tentativa da parte desidiosa de propor a rescisão, ou seja, será ônus do autor demonstrar que não teve oportunidade de acesso a tal prova antes da sentença ou acórdão.

E mais, a parte interessada deve demonstrar existência ignorada até então da prova ou, se conhecida, a impossibilidade da apresentação, no processo rescindendo. Não o fazendo, de futuro, a ação rescisória não será admitida.

Nesse sentido, "se alguém, ao ser demandado, alega que pagou, mas não consegue trazer o recibo, por desconhecer esse recibo ou por não saber onde o recibo se encontrava, ao ficar de posse desse documento poderá certamente promover a ação rescisória a partir desse pressuposto de que o fato estava alegado e de que, com o documento novo, o conjunto probatório vai sofrer uma alteração tal que poderá transformar aquele decreto de procedência em decreto de improcedência, ainda que parcialmente". ${ }^{100} \mathrm{O}$ documento novo em questão constituirá uma nova prova documental.

Destarte, provar a novidade da prova é condição de admissibilidade da própria ação rescisória, conforme preceitua a regra de distribuição do ônus da prova ${ }^{101}$ na forma do art. 373 , inciso I, do CPC/2015. ${ }^{102}$

98 GONÇALVES, Marcus Vinicius Rios. Direito processual civil esquematizado, p. 563.

99 BUENO, Cassio Scarpinella. Manual de direito processual civil, p. 628.

${ }^{100}$ RIZZI, Luiz Sérgio de Souza. Da ação rescisória. Revista de Processo, v. 26. p. 190.

${ }^{101}$ Sobre a distribuição do ônus da prova: LOPES, João Batista. Ônus da prova e teoria das cargas dinâmicas no novo Código de Processo Civil. Revista de Processo, São Paulo: RT, v. 37, n. 204. p. 231-242, fev. 2012. p. 231 e ss.

102 BAZZANEZE, Thaís. Distribuição dinâmica dos ônus probatórios: análise à luz do devido processo legal e do acesso à Justiça. Revista de Processo, São Paulo: RT, v. 37, n. 205, p. 55-88, mar. 2012.p. 70. 
Ainda, resta desconfigurada a hipótese de cabimento da ação rescisória por prova nova, se no processo primitivo, embora houvesse manifestação a seu respeito de eventual documento, a realização da prova era possível naquele tempo porque ele constava em órgãos públicos ou cartórios. ${ }^{103}$

\subsubsection{Princípio iura novit curia ou da adstrição para conhecimento de questão ex officio}

Qualquer dos incisos do art. 966 contém hipótese suficiente à rescisão, razão pela qual a pluralidade de fundamentação (mais de um inciso) redunda na cumulação de ações rescisória. ${ }^{104}$ Esse entendimento é pacífico. ${ }^{105}$ Também é pacífico que, se o fato que dá ensejo à procedência do juízo rescindens foi narrado na inicial da ação rescisória e houve apenas erro no enquadramento do inciso, será permitido ao Tribunal, no julgamento, emprestar qualificação jurídica adequada, ante a aplicação do princípio iura novit curia (o juiz conhece o direito) ${ }^{106} \mathrm{ou}$, em outra versão em brocardo com o mesmo sentido, naha mi factum, dabo tibi ius

${ }^{103}$ DONADEL, Adriane. A ação rescisória no direito processual civil brasileiro. Rio de Janeiro: Forense, 2008. p. 160.

${ }^{104}$ PEIXOTO, Ravi. Ação rescisória e capítulos de sentença: a análise de uma relação conturbada a partir do CPC/2015. In: DIDIER JR., Fredie (coord.); MACÊDO, Lucas Buril de; PEIXOTO, Ravi; FREIRE, Alexandre. Novo CPC - doutrina selecionada, v. 6: processo nos tribunais e meios de impugnação às decisões judiciais, p. 230.

${ }^{105}$ MOREIRA, José Carlos Barbosa. Considerações sobre a causa de pedir na ação rescisória. In: Temas de direito processual - quarta série. São Paulo: Saraiva, 1989. p. 205.

${ }^{106} \mathrm{O}$ objetivo dessa pesquisa é apresentar estudo no campo do processo civil, todavia verificamos a título de referência a seguinte ementa da justiça obreira: "Inexistência de inépcia - Se o autor descreve os fatos que, no entender dele, autorizaram a rescisão da sentença com base na tese de que há documento novo, cujo teor teria mudado a avaliação da autoridade sentenciante, não configura inépcia a simples falta de especificação do inciso, no art. 485 do CPC, em que se enquadra essa hipótese de rescindibilidade. Aplica-se ao caso o princípio iura novit curia, como já consolidado na jurisprudência do Tribunal Superior do Trabalho (Súmula n. 408, primeira parte). Agravo regimental provido. Decisão: acordam os Desembargadores do Pleno do Tribunal Regional do Trabalho da Sexta Região, por maioria, DAR provimento ao agravo regimental para determinar o processamento da ação rescisória; vencidos o Exmo. Juiz Relator e os Exmos. Desembargadores Zeneide Costa e Acácio Caldeira que negavam provimento ao agravo". (Tribunal Regional do Trabalho - AG em AR - 0031100-

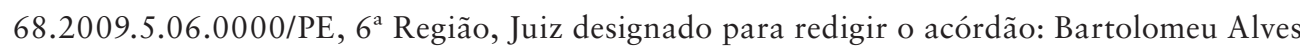
Bezerra, $3^{\text {a }}$ Turma, DJe 03.06.2011). Corresponde ao art. 485 do CPC/1973 o art. 966 do CPC/2015. 
(narra-me o fato, eu te darei o direito), cabe à parte discorrer sobre os fatos e, ao juiz, conceder o direito adequado à espécie. ${ }^{107}$

O problema reside quando a parte alega um inciso e o julgador visualiza o cabimento de outro, não alegado nem faticamente pela parte. Saliente-se que na petição inicial da ação rescisória não consta nenhuma alegação fática ou jurídica do pedido rescindente visualizado por qualquer dos julgadores da ação rescisória. Nesse caso, o magistrado poderá acolher a ação rescisória por outro fundamento não alegado pelo autor? Será que a questão é apenas de fundamentação ou ultrapassa os elementos fáticos e, assim, o fato não narrado não poderá ser conhecido? Eis a polêmica estabelecida.

Notadamente, o adágio iura novit curia não pode ser aplicado para ensejar que a parte se desobrigue de fornecer corretamente os fundamentos jurídicos do pedido e, muito menos, que o julgador supere os requisitos essenciais de toda ação rescisória, em especial a especificação do pedido. Todavia, em socorro da tese mais liberal, nessa linha, o julgador não precisa se ater aos fundamentos invocados pelas partes, mas deve estar baseado em fatos ligados ao fato-base da postulação, o que configura o princípio da adstrição. ${ }^{108}$ Mesmo o equívoco da parte autora na indicação do fundamento legal que ampara o cabimento da ação rescisória não impede seu processamento e julgamento, porém deve o autor precisar os fatos de maneira compreensível para que o juiz possa conceder a providência jurídica reclamada. A aplicação do princípio iura novit curia, nesse caso, não representaria grave violação do princípio dispositivo e do contraditório, pois a menção precisa da lei não é imprescindível. Cabe ao magistrado, dentro dos limites fáticos aportados no processo, aplicar o direito, sob o enquadramento jurídico que entender pertinente. ${ }^{109}$

107 "Não é inepta a inicial que descreve situação fática (pedido e causa de pedir) diversa do nome dado à ação, porquanto o que sobreleva é o brocardo narra mihi factum dabo tibi jus, notadamente se, como ocorre na espécie, há plena possibilidade de o réu se defender, conforme assegurado pela sentença e pelo acórdão recorrido. (...) Recurso especial não conhecido.” (STJ REsp 710.651/SE, Rel. Ministro Fernando Gonçalves, 4ª Turma, julgado em 04.10.2005, DJ 17.10.2005. p. 311).

${ }^{108}$ TJMG - Ação Rescisória 2.0000.00.237347-9/000 2373479-82.2000.8.13.0000, Rel. Des. Dorival Guimarães Pereira, DJ 22.11.2000.

109 “É necessário que uma das situações se configure, não importando o equívoco na invocação do dispositivo legal. Se erra a parte em escorar o fundamento em norma de lei, não implica a carência de ação desde que a descrição dos fatos conduz a depreender a hipótese de sustentação da lide. Não se revela primordial a invocação do dispositivo de lei no qual se ampara o pedido de autor, mas pela natureza do direito pleiteado." (RIZZARDO, Arnaldo. Limitações do trânsito em julgado e desconstituição da sentença, p. 300). Nesse mesmo sentido: "Processo civil. 
Tradicionalmente, não ocorrendo tal exceção, é assente que o juiz não pode acolher a ação rescisória por outro fundamento que não aquele alegado, pois, se acolhido um dos incisos não alegado, sequer faticamente, seria transmudar uma ação em outra, o que não é permitido pelo sistema, por ato do juízo, sem emenda regular da parte autora. Redundaria, sem delongas, na própria negação ao contraditório, pois, por óbvio, o réu será citado do teor da petição inicial e, daí, colhendo os elementos correlatos à defesa, seria surpreendido com um julgamento fora da tese dos autos. ${ }^{110}$

Assim, sendo omissa a petição inicial rescisória quanto aos fatos e fundamentos em torno de um dos incisos do art. 966 do CPC/2015, essa circunstância leva à impossibilidade de defesa, e, via de consequência, o juiz não poderá, segundo essa linha de pensamento, aplicar o princípio iura novit curia. Frise-se, não poderá passar ao conhecimento ex officio de outro inciso do art. 966 do CPC/2015.

Isso porque o brocardo invocado tem versão mais esclarecedora, qual seja, naha mi factum, dabo tibi ius. Ora, se o fato estiver narrado, há possibilidade da elaboração de defesa, e, sem prejuízo ao contraditório, então será possível a aplicação do direito. Mas, se os fatos alegados pelo autor são diversos, não se trata propriamente de adequação do fundamento da sentença, e sim de inovação do

Ação rescisória. Agravo regimental. Alegação de violação a literal disposição de lei. Condenação em litigância de má-fé. Indeferimento liminar da petição inicial. (...) 5. Na ação rescisória fundada no artigo 485, inciso V, do Código de Processo Civil, a indicação precisa de quais são os dispositivos legais tidos por violados é requisito essencial, e a agravante não indicou expressamente o artigo $5^{\circ}$, inciso LV, da Constituição. 4 . Ainda que se entenda admissível a indicação implícita do dispositivo legal tido por violado, desde que seja possível identificá-lo com segurança”. (TRF - AR 0056947-11.2007.4.03.0000, Rel. Juiz convocado Márcio Mesquita, 3ª Região, $1^{a}$ Seção, julgado em 06.11.2008, DJF3 21.11.2008). Não obstante, diverge o autor Marcelo Abelha Rodrigues quanto à aplicação do princípio iura novit cúria. (RODRIGUES, Marcelo Abelha. Manual de direito processual civil, p. 554). Corresponde ao art. 485, inciso V, do CPC/1973 o art. 966, inciso V, do CPC/2015.

110 "Ação rescisória. Petição inicial. Capitulação errônea no artigo 485 do CPC. Aplicação do princípio iura novit curia. Extinção do processo sem julgamento de mérito. Não configuração. Esta Corte firmou entendimento no sentido de não haver inépcia da inicial pelo simples fato de a parte indicar erroneamente o inciso da norma de regência que ampara o pedido de corte rescisório se, da análise dos fatos e fundamentos da causa de pedir invocados pela parte, o Tribunal puder dar a adequada qualificação jurídica, aplicando-se o princípio iura novit curia - item n. 32 da Orientação Jurisprudencial da SBDI.” (TST - ROAR 628.871/2000.0, Rel. Ministro Emmanoel Pereira, julgado em 02.12.2003, public. 02.04.2004). Corresponde ao art. 485 do CPC/1973 o art. 966 do CPC/2015. 
pedido, inovação do mérito. Além de ferir o contraditório, extrapolaria o limite devolutivo (o pedido), e o juiz passaria a advogar para a parte autora, o que é vedado no sistema positivo.

Esse sempre foi o entendimento de nossos Tribunais.

Ousamos ligeiramente discordar dessa conclusão, pois não há dispositivo específico sobre o assunto e o direito contemporâneo afasta-se cada vez mais de uma visão individualista para encampar a cosmovisão, permitindo ao magistrado aplicar o direito mais adequado ao caso, privilegiando, sempre que possível, uma interpretação social (arts. $4^{\circ}$ e $5^{\circ}$ da LINDB)..$^{111}$

Primeiro, resta reconhecer que, no caso de pluralidade de fundamentos, se um fundamento alegado for suficiente para a procedência da ação rescisória, não se estabelece o problema proposto, uma vez que, como já dito, na comprovação de qualquer dos fundamentos constantes dos incisos do art. 966 do CPC/2015 será igualmente apto à procedência da ação rescisória. Segundo, se ocorrente matéria de ordem pública que possa viabilizar a ação rescisória, sendo certo que o juiz deve conhecer tal matéria a qualquer tempo e em qualquer grau de jurisdição, até mesmo em ação rescisória, também tal problema não se estabelecerá, pois será o caso típico de conhecimento ex officio pelo Tribunal.

Assim, distanciando-se a solução de procedência da ação rescisória dos argumentos fáticos e do enquadramento jurídico trilhado pelo autor e não havendo questão de ordem pública que leve à procedência da ação rescisória, então existirá um problema real a ser resolvido nessa sede.

Defendemos que seja possível.

Veja-se que o único argumento contrário à inovação na decisão é calcado na nulidade do julgado por conta do ferimento ao princípio do contraditório. Todavia, a ação rescisória é a última chance de o autor ver o seu direito reconhecido. Assim, na busca da justiça e na entrega de uma tutela com a devida segurança jurídica, vale um maior cuidado no acesso à justiça. ${ }^{112}$

111 "Art. $4^{\circ}$ Quando a lei for omissa, o juiz decidirá o caso de acordo com a analogia, os costumes e os princípios gerais de direito. Art. $5^{\circ} \mathrm{Na}$ aplicação da lei, o juiz atenderá aos fins sociais a que ela se dirige e às exigências do bem comum." (Lei de Introdução às Normas do Direito Brasileiro - Decreto-lei n. 4.657, de 4 de setembro de 1942).

112 "O grau de imperfeição da decisão de mérito, no entanto, pode ser de consequências tão graves que venha a superar a própria necessidade de segurança imposta pela res judicata. 1 Daí a previsão da rescisória, que é, inegavelmente, um dos mais belos e complexos institutos da ciência jurídica. Trata-se, em última análise, de meio de impugnar-se decisões de mérito transitadas em julgado, desde que ocorrentes determinados requisitos. Destarte, não se confunde com o 
É que, uma vez afirmado o pedido de rescisão do capítulo da sentença, por qualquer dos incisos, a questão da rescisão desse mesmo capítulo pode ser fundamentada em fato e em respectivo inciso, verificados originalmente pelo julgador, pois se trata de tema de decisão que, assim sendo, passa pelo crivo do campo probatório (vale dizer, com base na verificação das provas dos autos), sendo autorizado o acolhimento ex officio da aferição do julgamento pelo Tribunal, ante o livre convencimento que norteia o julgamento. Deve-se apenas ter o cuidado de oportunizar o devido contraditório. ${ }^{113}$

Em outras palavras, ainda que o art. 319, inciso III, do CPC/2015 seja explícito em dizer que a exordial deva indicar "o fato e os fundamentos jurídicos do pedido", é importante observar que "não se confunde 'fundamento jurídico' com 'fundamento legal', sendo aquele imprescindível e este dispensável, em respeito ao princípio iura novit curia (o juiz conhece o direito)." ${ }^{114-115} \mathrm{Na}$ espécie, não se trata

recurso, que, não obstante também objetive o reexame de uma decisão, pressupõe a inocorrência da coisa julgada. Segundo Lopes da Costa, seria um misto de ação e de recurso ou 'uma ação-recurso ou um recurso-ação’.” (TEIXEIRA, Sálvio de Figueiredo. Ação rescisória - apontamentos. Revista dos Tribunais, v. 646, ago. 1989. p. 7; e Doutrinas Essenciais de Processo Civil, São Paulo: RT, v. 7, out. 2011. p. 1251).

${ }^{113}$ Em sentido contrário: "Recurso ordinário em ação rescisória - violação de lei. Decisão 'citra petita'. 1. Devendo haver correlação entre pedido e decisão, tem-se ser defeso ao juiz proferir julgamento "citra petita'." (TST - ROAR-3900-60.2008.5.19.0000 de 8a Turma, Magistrado Responsável: Maria Doralice Novaes, Juíza Convocada, julgado em 11.05.2010, public. 21.05.2010).

${ }^{114}$ Precedentes: STJ - REsp 477.415/PE, Rel. Ministro José Delgado, 1ª Turma, DJU 9.6.2003; STJ - REsp 1140420/SC, Rel. Ministro Mauro Campbell Marques, 2 a Turma, DJe 05.05.2011.

${ }^{115}$ No mesmo sentido, veja este julgado: "Agravo Interno no Agravo em Recurso Especial. Princípio da não surpresa. Art. 10 do CPC/15. Fundamento legal. Dever do juiz em se manifestar. Fundamento jurídico. Circunstância de fato qualificada pelo direito. Intimação das partes. Precedente. Prazo recursal. 15 dias úteis. Interposição posterior. Intempestividade configurada. Decisão mantida. 1. 'O 'fundamento' ao qual se refere o art. 10 do CPC/2015 é o fundamento jurídico - circunstância de fato qualificada pelo direito, em que se baseia a pretensão ou a defesa, ou que possa ter influência no julgamento, mesmo que superveniente ao ajuizamento da ação - não se confundindo com o fundamento legal (dispositivo de lei regente da matéria). A aplicação do princípio da não surpresa não impõe, portanto, ao julgador que informe previamente às partes quais os dispositivos legais passíveis de aplicação para o exame da causa. $\mathrm{O}$ conhecimento geral da lei é presunção jure et de jure’. - EDcl no REsp 1.280.825/RJ, Rel. Ministra Maria Isabel Gallotti, 4ª Turma, julgado em 27/06/2017, DJe 01/08/2017. 2. Verificada a intempestividade do recurso, deve ser não conhecido, independente de intimação da parte para se manifestar a respeito, inexistindo afronta ao art. 10 do CPC/15. 3. Iniciado o prazo recursal de 15 dias úteis em 23/set/2016, o termo final foi 14/OUT/2016, sendo, portanto, 
de invocação de fato novo em sede de ação rescisória, mas apenas de apresentação de novos fundamentos, coerentes com a causa de pedir, objetivando o acolhimento do pedido rescindente da sentença.

Assim, poderá, em sede de ação rescisória, o magistrado acolher a ação rescisória por outro inciso do art. 966 do CPC/2015, ainda que não alegado nem faticamente, desde que permita ao réu o devido contraditório. ${ }^{116}$ Ou seja, deverá qualquer dos julgadores da ação rescisória, antes de proferir seu voto sobre a decisão de mérito na ação rescisória, se entender ser esse o caso, como aqui tratado, então instar as partes, por despacho, homenageando-se o disposto no art. 10 do $\mathrm{CPC} / 2015,{ }^{117}$ a se manifestarem, esclarecerem eventual cabimento e apresentarem suas teses, indicando, no despacho que assim determinar, o documento dos autos e relacioná-lo com o inciso específico do art. 966 do CPC/2015. Tal decisão não incorrerá, é claro, em prejulgamento pelo julgador, pois será procedimento adotado visando apenas colher o necessário esclarecimento das partes. Também não se tratará de nenhum aditamento da inicial; pelo contrário, esse tema está enquadrado nas questões cognoscíveis ex officio, desde que a tese atinja o mesmo capítulo da sentença que se quer rescindir. O pedido de rescisão do capítulo deve estar formulado desde o início, na petição inicial, e, então, como defendemos, poderá o julgador prosseguir com o julgamento, com reconhecimento de outro

intempestivo o recurso apresentado em 19/out/2016. 4. Agravo interno não provido". (STJ AgInt no AREsp 1044597 MS 2017/0012005-0, Rel. Ministro Luis Felipe Salomão, julgado em 07.11.2017, T4 - Quarta Turma, DJe 14.11.2017).

${ }^{116}$ Mutatis mutandis, tal já ocorre nos embargos com efeito modificativo, em que não está prevista vista obrigatória à parte contrária sobre o teor dos embargos, todavia a jurisprudência já pacificou a necessidade do contraditório, quando o julgador vislumbrar que poderão ser providos os embargos para modificar a decisão. É uma prudência do magistrado para colher importante manifestação que, no mais das vezes, facilita o correto entendimento da controvérsia e propicia julgamento com maior segurança. Veja-se a ementa: "Efeito Modificativo. Recurso provido, com alteração do julgado. Os embargos de declaração podem ter efeitos modificativos se, ao suprir a contradição e o erro material, outro aspecto da causa tenha de ser apreciado como consequência necessária”. (TJSP - Embargos de Declaração 0039907-08.2009.8.26.0053, Rel. Rui Stoco, Comarca: São Paulo, 4ª Câmara de Direito Público, julgado em 10.09.2012, registro 13.09.2012).

117 Acerca do art. 10 do CPC/2015 e a princípio da não surpresa, consagrado por ele, veja a jurisprudência: "Reexame necessário - Apelação cível - Princípio da não surpresa - Art. 10 do CPC. Em atenção ao princípio da não surpresa e confiança materializados pelo art. 10 do CPC, salvo em casos de urgência, o magistrado não pode decidir com base em fundamento do qual as partes não tenham tido oportunidade de se manifestar". (TJMG - AC 10231150386598002 MG, Rel. Des. Jair Varão, julgado em 06.03.2018, public. 27.03.2018). 
inciso do art. 966. Todavia, não poderá o magistrado, ex officio, emprestar esse entendimento, via de regra, para ampliar a lide em pedido de rescisão de capítulo da sentença do qual não foi objeto da ação rescisória, salvo nulidade abrangida pela ordem pública. ${ }^{118}$

Em suma, os requisitos para aplicação ex officio de outro inciso, diverso do invocado pela parte, do art. 966 do CPC/2015, na ação rescisória, são: a) haver pedido de rescisão do mesmo capítulo da sentença em que se pretende a aplicação ex officio de outro inciso do art. 966 do CPC atual; e b) o julgador submeter "o direito em tese" às partes, possibilitando as devidas manifestações, tanto de autor como de réu, bem como de terceiros interessados, abrindo-se prazo razoável para pronunciamento sobre a aplicação desse outro inciso, em consonância com as provas dos autos.

\subsection{LEGITIMIDADE}

O tema legitimidade na ação rescisória deve ser analisado sob os enfoques ativo e passivo. O art. 967 do CPC/2015 esclarece a legitimidade ativa conferida a quem foi parte no processo em que proferida a decisão rescindível, a seu sucessor a título universal ou singular, ao terceiro juridicamente interessado, ao Ministério Público e a quem não foi ouvido no processo em que era obrigatória a sua intervenção. Nada dispõe acerca da legitimidade passiva.

Não obstante, por óbvio, a legitimidade passiva estará com quem, tendo figurado na ação, tenha sido atingido pela coisa julgada, ou seja, todos aqueles que figuraram como parte, exceto se for o autor da ação rescisória, por já ocupar o polo passivo. Essa totalidade é fato quando proposta a ação rescisória por terceiro ou pelo Ministério Público, uma vez que estes, como de ordinário, não terão figurado no processo de origem. Trata-se de litisconsórcio necessário passivo inicial.

Vejamos as particularidades de cada espécie.

\subsubsection{Polo ativo}

No âmbito da legitimidade ativa, têm-se como habilitados: a parte e o terceiro, mesmo assistente litisconsorcial ou simples, o Ministério Público, quer como

\footnotetext{
118 “A ação de rescisão do julgado, embora não necessária para desconstituir a sentença nula ou inexistente, pode servir de ensejo ou oportunidade para tanto, já que tais vícios são arguíveis e declaráveis em qualquer processo ou instância, e até mesmo ex officio." (THEODORO JÚNIOR, Humberto. Nulidade, inexistência e rescindibilidade da sentença. Doutrinas Essenciais de Processo Civil, São Paulo: RT, v. 6, out. 2011. p. 175).
} 
fiscal da lei nos casos de ausência da intervenção obrigatória ou na ocorrência de fraude à lei, quer como parte em todas as hipóteses de cabimento, ${ }^{119}$ e quem não foi ouvido no processo em que sua intervenção era obrigatória. ${ }^{120}$

A legitimidade ativa para a ação rescisória começa a ser definida já no art. 506 do CPC/2015, uma vez que a sentença faz coisa julgada entre as partes e terceiros eventualmente atingidos pelo comando da decisão de mérito, dada a potencialidade de produzir tais efeitos, razão pela qual têm legitimidade para a propositura da ação rescisória as partes do processo ou os seus sucessores, podendo estes ser a título universal ou singular. ${ }^{121}$ Ainda, não se descarta a hipótese de propositura da ação rescisória pelo Ministério Público, ${ }^{122}$ nos casos em que restar ausente sua intervenção obrigatória ou quando fundada em fraude à lei, uma vez manifesta a simulação ou a colusão entre as partes e caracterizada a necessidade de defesa da ordem jurídica, atuando o parquet como parte ou como fiscal da lei.

É que o inciso III do art. 967 do CPC/2015 apresenta três hipóteses em $n u$ merus apertus, em face da dicção do art. 127 da CF, que é mais abrangente, ao legitimar o Ministério Público para propor ação rescisória com base na defesa de interesse público indisponível. Anote-se também, no mesmo sentido de atrelar a legitimidade do Ministério Público, o dispositivo do art. 129, III, da CF em consonância com o teor da Lei n. 7.347/85, constitucionalmente recepcionada. ${ }^{123}$

A legitimidade do terceiro prejudicado é reconhecida ainda que o direito positivo considere a autoridade da coisa julgada adstrita ao dispositivo da sentença. Em verdade, a motivação da sentença está fora da abrangência da coisa julga-

119 "Muitos autores na doutrina negam a possibilidade de litisconsórcio necessário ativo. Com Cândido Rangel Dinamarco (Litisconsórcio. 6. ed. São Paulo: Malheiros, 2001. p. 233-239), entendo que ele é possível. Esse insigne jurista aponta alguns exemplos, dos quais reproduzirei apenas um. Se duas ou mais pessoas adquirem em condomínio um imóvel e depois verificam a diferença a menor ad mensuram, somente podem propor ação indenizatória ou rescisória contra o vendedor em conjunto." (GRECO, Leonardo. Concurso e cumulação de ações. Doutrinas Essenciais de Processo Civil, São Paulo: RT, v. 2, out. 2011. p. 223).

120 THEODORO JÚNIOR, Humberto. Curso de direito processual civil: execução forçada, processo nos tribunais, recursos e direito intertemporal - v. III. 48. ed. rev., atual. e ampl. Rio de Janeiro: Forense, 2016, p. 872.

${ }^{121}$ KLIPPEL, Rodrigo. Ação rescisória, p. 71.

${ }^{122}$ GODINHO, Robson Renault. O Ministério Público como substituto processual no processo civil. Rio de Janeiro: Lumen Juris, 2007. p. 19.

${ }^{123}$ MOREIRA, José Carlos Barbosa. Apontamentos para um estudo sistemático da legitimação extraordinária. In: . Direito processual civil (ensaios e pareceres). Rio de Janeiro: Borsoi, 1971. p. 60. 
da (art. 504, I, do CPC/2015), sendo apenas o conteúdo declaratório, constitutivo, condenatório ou mandamental, que veicula as partes e que é passível de preservação pela coisa julgada. Todavia, como esse conteúdo pode atingir outras pessoas físicas ou jurídicas que não integraram a lide, mesmo em sua esfera patrimonial e de direitos de outras naturezas, mas conversíveis em pecúnia, concretamente, aparecerá o interesse juridicamente tutelado, porquanto o atingimento direto ou indireto provocado pelo conteúdo da sentença legitima o terceiro à propositura da ação rescisória. Anote-se que a revelia não impede a propositura da ação rescisória, eis que o revel mantém a legitimidade, pois continua vinculado pela coisa julgada. ${ }^{124}$

$\mathrm{Na}$ formação de assistente litisconsorcial também o assistente poderá realizar a propositura da ação rescisória, pois facilmente se vê alguma titularidade da relação jurídica litigiosa. Todavia a doutrina não descarta a legitimidade do assistente simples, ${ }^{125}$ uma vez que poderá atuar como terceiro interessado nos moldes do art. 967, inciso II, do CPC/2015, desde que presente uma das hipóteses de cabimento dos incisos do art. 966 do CPC/2015..$^{126}$

Observe-se que a legitimidade ativa para a ação coletiva é extraordinária e restrita aos legitimados. Se um dos legitimados não propuser a ação e não estiver participando do processo, poderá ingressar no curso do processo, já que seria legitimado para propor a mesma ação; então, evitando-se a repropositura da ação e dando celeridade e rendimento ao processo em andamento, admite-se essa intervenção sui generis. O mesmo ocorre com a ação rescisória. Se o colegitimado não participou da ação matriz, poderá ele ingressar com a ação rescisória (legitimidade ativa), e, ainda que não tenha ajuizado a ação rescisória, poderá nela ingressar e prosseguir, porém sempre dará continuidade ao processo no estado em que se encontrar, não retroagindo ou anulando nenhum ato processual, permanecendo válidos para todos os efeitos legais. É que a facilitação da propositura da ação (que pode ser realizada por um dos colegitimados) deve se estender à ação

${ }^{124}$ VIDIGAL, Luís Eulálio de Bueno. Comentários ao Código de Processo Civil. São Paulo: RT, 1974. v. VI. p. 177.

125 "Ou seja, em relação ao assistente simples, a sentença projeta seus efeitos para fora do processo, não sob a forma de imutabilidade decorrente da coisa julgada, mas da justiça da decisão (CPC, art. 123). Por isso, parece-nos que terá interesse e legitimidade para a rescisória. Em contrapartida, se o terceiro interessado não ingressou como assistente simples, não é atingido pela justiça da decisão e não tem interesse em ajuizá-la”. (GONÇALVES, Marcus Vinicius Rios. Direito processual civil esquematizado, p. 558).

${ }^{126}$ TUCCI, José Rogério Cruz e. Limites subjetivos da eficácia da sentença e da coisa julgada nas ações coletivas, p. 42. 
rescisória, mantendo-se a proporcionalidade das exigências para a formação do processo. Assim, não há necessidade de citação nem dos substituídos nem dos colegitimados, especialmente aqueles que não participaram do processo matriz, posto que a ação rescisória, assim como o foi na ação matriz, tem aptidão para ser conhecida no mérito rescindendo e rescisório. ${ }^{127}$

Ainda, com o CPC de 2015, um novo inciso foi implementado ao dispositivo que se reserva a disciplinar a legitimidade para a ação rescisória (art. 967, correspondente ao antigo art. 487 do CPC/1973), em que se prevê a legitimidade daqueles que não foram ouvidos no processo, mas cuja intervenção era obrigatória. "É o caso, por exemplo, do curador especial em favor do réu revel citado fictamente ou do réu revel preso. Se eles não forem ouvidos e o juiz proferir decisão de mérito desfavorável ao curatelando, eles estarão legitimados a propor ação rescisória". ${ }^{128}$

${ }^{127} \mathrm{Na}$ linha da discussão da inclusão obrigatória dos substituídos na ação coletiva, muito embora o voto condutor tenha se pronunciado no sentido contrário, conforme ementa: "Processo civil. Embargos de divergência. Ação rescisória. Propositura apenas em face de parte dos integrantes da relação originária. Litisconsórcio necessário. Correção. Decadência. 1. Nas ações rescisórias integrais devem participar, em litisconsórcio unitário, todos os que foram partes no processo cuja sentença é objeto de rescisão. 2. A propositura de ação rescisória sem a presença, no polo passivo, de litisconsorte necessário somente comporta correção até o prazo de dois anos disciplinado pelo art. 495 do CPC. Após essa data, a falta de citação do litisconsorte implica a decadência do direito de pleitear a rescisão, conduzindo à extinção do processo sem resolução do mérito. 3. Embargos de divergência conhecidos e providos. Julgamento por maioria”. Ficamos com a conclusão dos dois votos vencidos, nos seguintes termos: voto vencido, Ministro Napoleão Nunes Maia Filho: "Não é possível a extinção da ação rescisória sem o julgamento do mérito, por ausência de citação de litisconsórcio necessário dentro do prazo decadencial de 2 anos, na hipótese em que foi citado para a rescisória originada de ação coletiva versando sobre direitos homogêneos apenas o sindicato da categoria, porque este representa ou substitui as partes individuais, que são os seus integrantes, devendo-se prestigiar a simplificação da composição da relação processual para que as coisas fluam com mais rapidez e racionalidade, evitando a formação do chamado polo multitudinário". Voto vencido, Ministro Raul Araújo: "Não ocorre a extinção da ação rescisória sem o julgamento do mérito, por ausência de citação de litisconsórcio necessário dentro do prazo decadencial de 2 anos, na hipótese em que foi citado apenas o sindicato da categoria para a rescisória proposta pela Fazenda Pública, porque, além de não se poder usar de duas lógicas com pesos absolutamente distintos, uma facilitando a propositura da ação pelo sindicato e outra dificultando a rescisória da Fazenda, a identificação de todos os filiados de um sindicato pela Fazenda é absolutamente inviável em ação rescisória, que tem prazo para ser proposta”. (STJ - EREsp 676.159/MT, Rel. Ministra Nancy Andrighi, Corte Especial, julgado em 01.12.2010, DJe 30.03.2011). Corresponde ao art. 495 do CPC/1973 o art. 975 do CPC/2015.

${ }^{128}$ GONÇALVES, Marcus Vinicius Rios. Direito processual civil esquematizado, p. 558-559. 
Convém ressaltar que, nos termos do art. 393, caput e parágrafo único, do CPC/2015, não será cabível a ação rescisória para o sucessor do de cujus que alegar erro de fato ou coação na confissão deste, uma vez que a demanda pertinente será a ação anulatória, nos termos do art. 966, $\mathbb{S} 4^{\circ}$, do CPC/2015. ${ }^{129}$

\subsubsection{Polo passivo}

De outro lado, quanto à legitimidade passiva, como regra geral na ação rescisória, muito embora não haja dispositivo legal expresso, é corrente a lição de que todos que tomaram parte no processo e que foram atingidos pela coisa julgada da decisão rescindenda são titulares do jurídico interesse nos seus efeitos e, via de consequência, serão litisconsortes necessários na ação rescisória. ${ }^{130}$

Contudo, sempre que possível, deve-se aproveitar o processo, dando-lhe máximo rendimento em função da resolução do direito material, máxime quando não haja regras expressas no campo processual. Não pode o processo ser um entrave à realização do direito material. ${ }^{131}$

Assim, como o interesse jurídico nos efeitos da coisa julgada pode não afetar a todos os partícipes do processo, a legitimidade passiva pode não envolver todos, excluindo um ou alguns dos litisconsortes. Esse resguardo se deve a casos de litisconsórcio facultativo simples, porquanto a coisa julgada impugnada (capítulo da sentença) não necessariamente possui identidade e correspondência com todos os litisconsortes, senão com um ou alguns destes, de acordo com sua pretensão do direito e respectiva tutela. Portanto, ocorrendo tal hipótese, cabendo a rescisão parcial do julgado, a legitimidade passiva dar-se-á apenas com relação a quem possa ser prejudicado com tal pedido rescindente e eventual pedido rescisório. ${ }^{132}$ Essa é a hipótese de propositura da ação rescisória por uma das partes. ${ }^{133}$

${ }^{129}$ MEDINA, José Miguel Garcia. Novo Código de Processo Civil comentado, p. 689.

${ }^{130}$ BARIONI, Rodrigo Otávio. Legitimidade passiva na ação rescisória. In: NERY JÚNIOR, Nelson; WAMBIER, Teresa Arruda Alvim (Coord.). Aspectos polêmicos e atuais dos recursos cíveis e assuntos afins. São Paulo: RT, 2011. v. 12. p. 379.

${ }^{131}$ Veja-se o seguinte trecho do julgado no Colendo Superior Tribunal de Justiça: "O julgamento da causa não resta frustrado ante a ausência de expressa indicação do dispositivo legal em que a parte autora ampara sua pretensão, quando há fundamentação suficiente para se inferir o pedido rescisório. (...) Ação rescisória julgada procedente”. (STJ - AR 3.382/PR, Rel. Ministro Arnaldo Esteves Lima, $3^{\text {a }}$ Seção, julgado em 23.06.2010, DJe 02.08.2010).

132 À luz do precedente, no voto condutor constou que "a ação rescisória constitui um remédio excepcional, cuja função é extremamente nobre, pois visa a retirar do mundo jurídico decisões judiciais que já transitaram em julgado e que estão produzindo efeitos no mundo fático, mas que na verdade são decisões que padecem de algum vício muito sério, não percebido no andamento 
Todavia, quando for proposta por terceiro ou Ministério Público, a regra geral é que deverá envolver no polo passivo todos aqueles que foram parte no processo primitivo. Não poderá o terceiro ou Ministério Público escolher a quem deseja processar, pois a coisa julgada, em tese, diz respeito ao ganhador e ao perdedor, ao autor e ao réu da ação originária. Na pluralidade objetiva e subjetiva (lides e partes), em havendo o litisconsórcio facultativo na ação originária, sendo, portanto, defensável que a decisão de mérito se conserve na inteireza para uns e seja desfeita para outros, caracterizadas, portanto, a existência de pretensões autônomas, então será possível o ajuizamento também por terceiro juridicamente interessado ou pelo Ministério Público, adotando-se como réus somente os atingidos pelo pedido rescindente. ${ }^{133}$

Atente-se, porém, que, se o regime for o litisconsórcio necessário, mesmo falecendo uma das partes antes da citação, esta deve ocorrer na pessoa dos herdeiros, e dentro do prazo razoável, sob pena de operar-se a decadência da ação. ${ }^{134}$

do processo. Por tal razão, a ação rescisória permite a sua extirpação do mundo jurídico, sobretudo para fulminar os efeitos dos vícios que possam estar produzindo ou que poderiam produzir”. Assim, a decisão foi ementada, in verbis: “Ação rescisória. Seguro obrigatório. Seguradora líder. Inclusão no polo passivo. Inexistem prejuízos pela não inclusão da Líder no polo passivo, mesmo na figura de litisconsorte”. (TJRS - AR 70.043.373.927/RS, 3 Grupo Cível, Rel. Des. Romeu Marques Ribeiro Filho, julgado em 23.03.2012).

${ }^{133}$ Nesse sentido, a seguinte ementa: "Processual civil. Ação rescisória. Regime de litisconsórcio. Acórdão rescindendo proferido em ação proposta mediante litisconsórcio ativo facultativo comum. Possibilidade de rescisão parcial. 1. Segundo dispõe o art. 47 do CPC, 'Há litisconsórcio necessário, quando, por disposição de lei ou pela natureza da relação jurídica, o juiz tiver de decidir a lide de modo uniforme para todas as partes'. Relativamente à ação rescisória, não havendo disposição legal a respeito, o litisconsórcio necessário somente ocorrerá se a sentença rescindenda não comportar rescisão subjetivamente parcial, mas apenas integral, para todas as partes envolvidas na ação originária. 2. Tratando-se de sentença proferida em ação proposta mediante litisconsórcio ativo facultativo comum, em que há mera cumulação de demandas suscetíveis de propositura separada, é admissível sua rescisão parcial, para atingir uma ou algumas das demandas cumuladas. Em casos tais, qualquer um dos primitivos autores poderá promover a ação rescisória em relação à sua própria demanda, independentemente da formação de litisconsórcio ativo necessário com os demais demandantes; da mesma forma, nada impede que o primitivo demandado promova a rescisão parcial da sentença, em relação apenas a alguns dos primitivos demandantes, sem necessidade de formação de litisconsórcio passivo necessário em relação aos demais. Precedente: REsp 1.111.092, $1^{\text {a }}$ Turma, DJe 01.07.2011. 3. Agravo regimental a que se nega provimento". (STJ - AgRg no Ag 1.308.611/BA, Rel. Ministro Teori Albino Zavascki, $1^{\text {a }}$ Turma, julgado em 21.08.2012, DJe 27.08.2012). Corresponde ao art. 47 do CPC/1973 o art. 114 do CPC/2015.

${ }^{134}$ É que, “decorrido o prazo decadencial para interposição da rescisória (CPC, art. 495) já não pode a ação ser proposta contra novo réu, sendo, consequentemente, impossível a regulariza- 
Por fim, nas ações em que figurarem interessados indeterminados, como na ação de usucapião, somente aqueles que tomaram parte na ação é que serão litisconsortes necessários, mantendo-se a citação por edital dos demais interessados.

\subsubsection{Litisconsórcio e o prazo para ajuizamento}

Em ação rescisória não se tem como inafastável o litisconsórcio necessário, posto que é dispensável a citação de todos os vencedores na demanda julgada pela decisão rescindenda, uma vez que entre eles haja o litisconsórcio facultativo.

Essa observação ganha total significado quando se estuda a contagem do prazo para a propositura da ação rescisória. Verifica-se que, sendo obrigatória a citação de todos os litisconsortes na ação rescisória, sob o regime do litisconsórcio passivo necessário, a propositura da ação rescisória deve invariavelmente acontecer dentro do biênio legal, em relação a todos os demandados. Em sendo caso de litisconsórcio passivo necessário, deixando-se de propor a ação contra um dos litisconsortes e expirado o prazo de dois anos, então não se poderá mais incluir, por emenda da petição inicial rescisória, o litisconsorte omisso, porque operada a decadência. ${ }^{135}$

ção da relação processual (AR 2.009/PB, Rel. Ministro Teori Albino Zavascki, $1^{a}$ Seção, unânime, DJ 03-05-2004, p. 86). Não sendo citada uma das partes que foi coautora na ação em que proferida a decisão rescindenda, fica caracterizada a inexistência do litisconsórcio passivo necessário, ocorrendo a decadência em virtude do transcurso do prazo previsto no art. 495 do Código de Processo Civil. Ação rescisória julgada extinta”. (AReg. em AR 2003.04.01.015682-4/RS, Rel. Des. Federal João Batista Pinto Silveira, julgado em 05.11.2009). No mesmo sentido, com estas e outras referências em precedentes, vide: TRF3 - Ação Rescisória n. 0005543-62.2000.4.03.0000/MS (AR 2000.03.00.005543-6), Rel. Des. Federal Cecilia Mello, DJ 04.05.2012. Corresponde ao art. 495 do CPC/1973 o art. 975 do CPC/2015.

${ }^{135}$ É cristalino esse entendimento, conforme julgado que se colaciona: "Processo civil. Embargos de divergência. Ação rescisória. Propositura apenas em face de parte dos integrantes da relação originária. Litisconsórcio necessário. Correção. Decadência. 1. Nas ações rescisórias integrais devem participar, em litisconsórcio unitário, todos os que foram partes no processo cuja sentença é objeto de rescisão. 2. A propositura de ação rescisória sem a presença, no polo passivo, de litisconsorte necessário somente comporta correção até o prazo de dois anos disciplinado pelo art. 495 do CPC. Após essa data, a falta de citação do litisconsorte implica a decadência do direito de pleitear a rescisão, conduzindo à extinção do processo sem resolução do mérito. 3. Embargos de divergência conhecidos e providos”. (STJ - EREsp 676.159/MT, Rel. Ministra Nancy Andrighi, Corte Especial, julgado em 01.12.2010, DJe 30.03.2011). Corresponde ao art. 495 do CPC/1973 o art. 975 do CPC/2015. 
Essa circunstância, todavia, não se configura em todos os casos submetidos à ação rescisória. Em suma, no que tange às sentenças proferidas nas ações propostas sob o regime do litisconsórcio ativo facultativo simples, é cristalina a admissão de sua rescisão parcial. Releva notar que, nesses casos, a ação matriz, proposta por vários autores, representa apenas singela cumulação de demandas em que, dada a situação, não poderia ser impedida a propositura individual, sendo que tal aglutinação em único processo, pela faculdade contida na afinidade de interesses dos demandantes, não pode transformar a opção pelo litisconsórcio, nos moldes do art. 113 do CPC/2015, em prejuízo para qualquer das partes. ${ }^{136}$

Nesses casos, a tutela individual deve ser preservada, com todos os direitos inerentes, inclusive acesso processual, como se tivesse sido proposta ação individualmente, pois não há diferença significativa que possa produzir um resultado diverso no plano material. Tratando-se de sentença rescindenda atrelada à ação proposta em litisconsórcio ativo facultativo (assim entendida aquela constituída pelo simples cúmulo de demandas que não teriam o óbice de serem propostas separadamente e que suportam soluções diversas), também não se pode olvidar do cabimento da ação rescisória, ainda que com rejulgamento do feito (art. 974 do CPC/2015), em face de um, alguns ou todos os litisconsortes facultativos da ação matriz, eis que submetidos, nesta sede, a igual regime litisconsorcial. ${ }^{137}$ Qualquer dos autores poderá promover a ação rescisória, pois não se trata de obrigatoriedade na formação de litisconsórcio ativo necessário com todos os outros autores; do mesmo modo, não fica afastada a hipótese de um primitivo réu intentar o pedido de rescisão parcial da decisão de mérito, em face somente de alguns dos autores primitivos, pois não há obrigatoriedade de formação de litisconsórcio passivo necessário em relação a todos os outros autores do processo em que proferida a sentença rescindenda. ${ }^{138}$

${ }^{136}$ A doutrina fornece bons exemplos dessa situação em que se forma o litisconsórcio facultativo comum, no qual a situação jurídica material é perfeitamente cindível, veja-se o seguinte trecho: "é o caso de várias vítimas de um só acidente rodoviário postulando condenação da mesma empresa ao ressarcimento; também o de uma ação de cobrança movida ao mutuário e ao fiador; ou uma de servidores à Fazenda Pública, visando a vantagens análogas". Com relação a esses casos "o que se tem é uma pluralidade jurídica de demandas, também unidas só formalmente; cada um dos litisconsortes é parte legítima apenas com referência àquela porção do objeto do processo que lhe diz respeito, e, consequentemente, entende-se que seu petitum se reduz a essa parcela. Trata-se efetivamente de um cúmulo de demandas, não só subjetivo mas também objetivo, na medida em que à pluralidade de sujeitos corresponde uma soma de pedidos, todos eles amalgamados no complexo objeto que esse processo tem". (DINAMARCO, Cândido Rangel. Litisconsórcio, 8. ed., p. 85-86).

${ }^{137}$ FUX, Luiz. Curso de direito processual civil, 4. ed., v. I, p. 691.

138 "O princípio geral, parece-nos, é o de que devem integrar o contraditório todos aqueles que eram partes no feito anterior, ao ser proferida a sentença (lato sensu) rescindenda." Mais adiante: 


\subsection{4 llegitimidade da parte excluída da lide originária}

Em outra possibilidade, aquele que foi excluído da ação primitiva, tendo sido considerado ilegítimo, não poderá propor ação rescisória, posto que a coisa julgada não lhe diz respeito, uma vez excluído do julgamento meritório. ${ }^{139}$

Da mesma forma e pelo mesmo fundamento, não poderá figurar como demandado no pedido rescindendo nem no rescisório, uma vez que aquele que fora excluído da lide e considerado ilegítimo não poderá ser prejudicado pela autoridade da coisa julgada material.

Aquele declarado ilegítimo será, para todos os efeitos, terceiro desinteressado no plano jurídico.

\subsubsection{Legitimidade de terceiro e legitimação extraordinária}

Pode ocorrer a hipótese de um terceiro, que não participou da ação primitiva, mas sendo legitimado para integrar o polo passivo daquela ação, querer integrar o processo em que formulado o pedido rescisório.

Por exemplo, quando visar à desconstituição do pagamento de honorários advocatícios fixados em sucumbência, o advogado, embora não tendo participado do processo primitivo, terá interesse jurídico legítimo na sua participação como parte na ação rescisória. ${ }^{140-141}$

\footnotetext{
"ressalve-se que, se se tratar de sentença objetivamente complexa, e o pedido de rescisão visar apenas um (ou alguns) dos distintos capítulos, será desnecessária a citação daquele(s) a quem, conquanto parte(s) no processo anterior, não $\operatorname{diga}(\mathrm{m})$ respeito o(s) capítulo(s) rescindendo(s). Assim, v.g., caso tenha havido denunciação da lide, e o denunciado queira rescindir a sentença na parte em que reconheceu, em face dele, o direito regressivo do denunciante, bastar-lhe-á, na rescisória, fazer citar este último. Análoga disciplina se observará se, no processo anterior, houve cumulação subjetiva de ações, com litisconsórcio sujeito ao regime comum, e só se pretende a rescisão no tocante a um (ou a alguns) dos litisconsortes". (MOREIRA, José Carlos Barbosa. Comentários ao Código de Processo Civil, 12. ed., v. V, p. 173).

${ }^{139}$ BARIONI, Rodrigo Otávio. Legitimidade passiva na ação rescisória, p. 382.

${ }^{140}$ SICA, Heitor Vitor Mendonça. Breves comentários ao art. 20 do CPC, à luz da jurisprudência do STJ. Revista de Processo, São Paulo: RT, v. 37, n. 207, p. 345-384, maio 2012. p. 350.

141 "A ação rescisória, quanto ao capítulo da sentença que fixa honorários advocatícios, deve ser admitida se observada uma das hipóteses previstas no art. 966 do CPC/2015. Assim, 'a ação rescisória é cabível para discutir o regramento objetivo da fixação da verba honorária, notadamente quando no acórdão rescindendo inexiste qualquer avaliação segundo os critérios previstos nas alíneas $a, b$ e $c$ do art. 20 do CPC [de 1973, correspondente ao art. 85 do CPC/2015]' (STJ, REsp 1.264.329/RS, rel. Min. Mauro Campbell Marques, 2. ${ }^{a}$ T., j. 20.11.2012), mas 'não
} 
O mesmo raciocínio se dá quando ocorre a substituição processual inter vivos ou causa mortis, pois o cessionário, o herdeiro ou legatário será legitimado para a ação rescisória.

Diferentemente é o que ocorre na legitimação extraordinária, pois somente o substituto processual (e não o substituído) poderá participar na ação rescisória. ${ }^{142}$

\subsection{PEDIDOS RESCINDENSE RESCISORIUM}

Em face dos momentos distintos do julgamento, comportando o juízo rescindente e o juízo rescisório, naturalmente a petição inicial levará em conta esses dois pedidos - vide art. 974 do $\mathrm{CPC} / 2015 .^{143}$

Porém, ainda que raros, há casos em que a satisfação do autor da ação rescisória é alcançada com base exclusivamente no pedido rescindente, ou seja, a rescisão (anulação) da decisão atacada já basta ao caso concreto, não necessitando o tribunal proferir nova decisão. ${ }^{144}$ Isso ocorre quando a decisão rescindenda é de reconhecimento da incompetência absoluta, sendo que, uma vez procedente a ação rescisória, reverte-se a decisão e o processo originário retomará normalmente seu curso, com instrução e julgamento perante o juízo competente.

Outro exemplo da impossibilidade jurídica de realizar o rejulgamento da causa consiste em que, "proposta ação rescisória por fraude à lei, após o juízo de rescisão nada mais haverá a fazer, pois outra decisão responderia a um pedido em fraude à lei. Assim também ocorrerá quando for alegada a ofensa à coisa julgada. Fácil concluir que incabível pedir acumulação de juízos, pois será suficiente rescindir e em caso de rejulgamento haveria nova ofensa à coisa julgada." ${ }^{145}$

cabe ação rescisória para discutir a irrisoriedade ou a exorbitância de verba honorária' (STJ, AgRg no AREsp 320.149/PE, rel. Min. Humberto Martins, 2. ${ }^{a}$ T., j. 13.08.2013).” (MEDINA, José Miguel Garcia. Novo Código de Processo Civil comentado, p. 1387).

142 "Se, no outro processo, havia substituição processual, ocupando algum legitimado extraordinário a posição de autor ou de réu, e subsiste a legitimação extraordinária, é da participação desse substituto que se tem de cogitar na rescisória." (MOREIRA, José Carlos Barbosa. Comentários ao Código de Processo Civil, 12. ed., v. V, p. 173).

${ }^{143}$ NERY JÚNIOR, Nelson. Código de Processo Civil comentado. 3. ed. São Paulo, RT, 1997. p. 706.

${ }^{144}$ BUENO, Cassio Scarpinella. Manual de direito processual civil, p. 631.

145 "Concluindo: a substituição, o rejulgamento, só não ocorrerá nesses raros casos; nos demais, se houver a rescisão, haverá rejulgamento e a competência será do próprio Tribunal. Não haverá possibilidade, também, salvo exceções, de se baixar o processo para o julgamento no primeiro grau. Esse juízo de rejulgamento compete ao próprio Tribunal.” (RIZZI, Luiz Sérgio de Souza. Da ação rescisória. Revista de Processo, v. 26, p. 191). 
Nesses casos, não há cabimento para o juízo rescisório, por absoluta incompatibilidade. ${ }^{146}$

Logo, não há ação rescisória sem pedido desconstitutivo, ${ }^{147}$ porém o que poderá existir ou não é a cumulação do pedido de novo julgamento da ação.

Desse modo, via de regra, o autor deve cumular na petição inicial da ação rescisória o pedido de rescisão com o pedido de julgamento. A exceção a esse preceito está nos casos em que o pedido rescindens já esgota a matéria para solução do caso no âmbito do tribunal.

Contudo, o art. 968, I, do CPC/2015 é taxativo ao aduzir que o autor deve "cumular ao pedido de rescisão, se for o caso, o de novo julgamento da causa", ou seja, ao menos no sentido literal, extrai-se que o autor terá que formular expressamente o pedido. Assim, se levado em consideração o texto da lei, não havendo formulação pelo autor dos pedidos adequados, o Tribunal não poderá, ex officio, avançar no rejulgamento da causa, ante a violação da coisa julgada. ${ }^{148}$

Nesse sentido, parcela da doutrina defende que a falta de atendimento pelo autor da cumulação do pedido é passível de acarretar a inépcia da inicial, haja vista o princípio dispositivo e a inércia da jurisdição. ${ }^{149}$

Esse entendimento, embora limitado e passível de críticas, coaduna-se com o dispositivo do art. 322 do CPC/2015, segundo o qual os pedidos devem ser certos, exceto os pedidos de condenação no pagamento de juros, correção monetária e honorários e despesas processuais.

${ }^{146}$ MOREIRA, José Carlos Barbosa. Comentários ao Código de Processo Civil, 11. ed., v. V, p. 177. 147 "O acolhimento de qualquer das hipóteses previstas no art. 485 do CPC, acarreta no juízo rescindente." (CORTEZ, Cláudia Helena Poggio. A impugnação da coisa julgada por meio de ação rescisória. 2012. p. 61).

148 "Quando a rescindibilidade disser respeito unicamente a capítulo dependente, embora seja possível ao autor da rescisória limitar a abrangência do iudicium rescindens, o tribunal não poderá contrariar o que restou decido no capítulo prejudicial. A coisa julgada referente ao capítulo prejudicial não pode ser vulnerada no julgamento da rescisória, porquanto não constitui seu objeto.” (BARIONI, Rodrigo Otávio. Ação rescisória e recursos para os tribunais superiores, p. 147).

149 "Nos termos do CPC, art. 488, a petição da Ação Rescisória deve atender, além dos requisitos gerais contidos no art. 282, alguns outros mais específicos, como o pedido de cumulação do 'iudicium rescindentes' e do 'iudicium rescisorium', se for o caso, sob pena de inépcia da inicial.” (STJ - REsp 264.513/PB, Rel. Ministro Edson Vidigal, 5ª Turma, julgado em 24.10.2000, DJ 04.12.2000. p. 93). No mesmo sentido: THEODORO JÚNIOR, Humberto. Código de Processo Civil anotado. Colaboradores: Humberto Theodoro Neto, Adriana Mandim Theodoro de Mello, Ana Vitoria Mandim Theodoro. 14. ed. São Paulo: Forense, 2010. p. 452). Correspondem aos arts. 282 e 488 do CPC/1973, respectivamente, os arts. 319 e 968 do CPC/2015. 
Não obstante, outra parcela da doutrina, de forma mais branda, entende que a cumulação de pedido não é exigência absoluta, tendo em vista que, nos casos em que comportar o duplo pedido, é decorrência lógica da desconstituição da decisão rescindenda o rejulgamento da causa. O novo julgamento é pedido implícito. ${ }^{150-151}$

Observe-se que o art. $968, \mathbb{S} 3^{\circ}$, do $\mathrm{CPC} / 2015$ não faz referência à ausência de cumulação do pedido de rejulgamento como causa de indeferimento da ação rescisória. Também não haverá qualquer prejuízo ao réu quanto ao exercício do contraditório. ${ }^{152}$

Contudo, diante da observância do princípio da instrumentalidade das formas $^{153}$ e do disposto no art. 10 do CPC/2015, entendendo-se pela obrigatoriedade do pedido de novo julgamento, será perfeitamente cabível ao juiz abrir o prazo para que o autor realize a emenda da inicial, conforme disposto no art. 329, inc. I, do CPC/2015, sob pena de indeferimento da inicial. ${ }^{154}$

Mas esse não parece ser o melhor entendimento. Desnecessária se afigura a emenda para incluir o pedido rescisório. Trata-se de pedido implícito.

150 "Embora preveja expressamente o art. 488, I, do CPC a obrigatoriedade do autor cumular o pedido de rescisão e, se for o caso, de novo julgamento, a cumulação de pedidos não é exigência formal absoluta, devendo ser abrandado o rigor do referido dispositivo. Considera-se implicitamente requerido o novo julgamento da causa, desde que seja decorrência lógica da desconstituição da sentença ou do acórdão rescindendo. (STJ, 2 ${ }^{\mathrm{a}}$ Turma, REsp 783.516, Ministro Eliana Calmon, julgado em 19.06.2007, DJU 29.06.2007).” (NEGRÃO, Theotonio; GOUVÊA, José Roberto Ferreira; BONDIOLI, Luís Guilherme Aidar; FONSECA, João Francisco Naves da. Código de Processo Civil. 44. ed. atual. e reform. São Paulo: Saraiva, 2012. p. 610). Corresponde ao art. 488, inciso I, do CPC/1973 o art. 968, inciso I, do CPC/2015.

151 "Partindo-se da compreensão do processo como instrumento de tutela do direito, razoável admitir-se que, sendo o pedido de novo julgamento uma consequência lógica da rescisão da decisão, o pressuponha o órgão jurisdicional implicitamente pedido (STJ, 2 a Turma, REsp 783.516/ PB, rel. Min. Eliana Calmon, j. 19.06.2007, DJ 29.06.2007, p. 541”. (MARINONI, Luiz Guilherme; ARENHART, Sérgio Cruz; MITIDIERO, Daniel. Novo Código de Processo Civil comentado, p. 1028).

${ }^{152}$ Cf. BARIONI, Rodrigo Otávio. Ação rescisória e recursos para os tribunais superiores, p. 156; YARSHELL, Flávio Luiz. Ação rescisória - juízo rescindente e rescisório, p. 356.

${ }^{153}$ NEVES, Daniel Amorim Assumpção. Manual de direito processual civil. 2. ed. São Paulo: Método, 2010. p. 740.

154 "No caso da rescisão por violação ao direito à prova, inclusive oportuniza-se reabrir a instrução para respectiva produção.” (NEGRÃO, Theotonio; GOUVÊA, José Roberto Ferreira; BONDIOLI, Luís Guilherme Aidar; FONSECA, João Francisco Naves da. Código de Processo Civil, 44. ed., p. 616). 
Embora existam entendimentos considerando a inicial inepta ou julgando extinto o processo por falta daquele pedido, o certo é que tal pedido de cumulação dos dois juízos, rescindens (rescisão da sentença) e rescisorium (novo julgamento da causa), pode ser considerado como implícito, eis que decorrente da lei.

O Tribunal, diante do caso a ele apresentado, não pode se omitir em entregar a prestação jurisdicional. Assim, uma vez rescindida uma decisão, outra deve substituí-la, aplicando-se, se for o caso, a tese do pedido implícito.

\subsection{PROVAS}

É importante também destacar a particularidade das provas no processamento da ação rescisória, haja vista que a competência originária dos tribunais (STF, STJ, TJ, TRF) provoca diferenças no modelo de produção de provas, padrão aquele adotado no procedimento ordinário. ${ }^{155}$

Saliente-se que, em regra, três etapas devem ser percorridas no julgamento da ação rescisória: o exame da admissibilidade, o julgamento rescindente e o rescisório. Nesta última, admite-se a dilação probatória, nas duas etapas anteriores serão admitidas somente provas pré-constituídas. ${ }^{156}$

155 “O Código acolheu o princípio dispositivo, segundo o qual o juiz deve julgar segundo o alegado pelas partes (iudex secundum allegata et probata partium iudicare debet). Mas o abrandou, permitindo a iniciativa probatória do juiz (v. Exposição de Motivos n. 18), haja vista que a publicização do processo e a socialização do direito implicam, cada vez mais, a busca pela verdade real. $\mathrm{O}$ juiz, entretanto, somente deverá tomar a iniciativa probatória quando a prova se fizer necessária 'ao conhecimento da verdade que interessa ao melhor e mais justo julgamento da causa'. Essa iniciativa reclama, no entanto, estado de perplexidade do julgador em face de provas contraditórias, confusas, incompletas ou de cuja existência o juiz tenha conhecimento. A iniciativa probatória do juiz pode ocorrer em qualquer fase, uma vez que a mesma não se sujeita à preclusão." (TEIXEIRA, Sálvio de Figueiredo. Código de Processo Civil anotado. 6. ed. São Paulo: Saraiva, 1996. p. 98).

${ }^{156}$ No voto do relator no REsp 262.978/MG, da lavra do Ministro Barros Monteiro, restou assentado que: "Julgado improcedente o pedido em $1^{\mathrm{o}}$ grau, a $5^{\mathrm{a}}$ Câm. Civil do Tribunal de Alçada do Estado de Minas Gerais não conheceu do recurso adesivo interposto pela ré, e, de ofício, anulou a sentença, a fim de que se proceda à instrução processual. (...) Em matéria relacionada com a instrução probatória, não há falar-se em preclusão para o Juiz. Tal é a orientação de há muito traçada pelo STJ (REsp 12.223/BA, 61.107/PR e 431.941/DF, todos de minha relatoria). Num dos primeiros recursos apreciados por este órgão fracionário, assentara-se que 'a norma do art. 473 do $\mathrm{CPC}$, alusiva à preclusão das 'questões já decididas', dirige-se às partes, não ao Juiz, máxime em matéria probatória, e sob o amparo inclusive do art. 130 do CPC' (REsp 13/SP, relator designado o Sr. Ministro Athos Carneiro). Assim se decidiu, por 
É que para análise da admissibilidade bastará mera análise do preenchimento dos requisitos de processamento da inicial. $\mathrm{Na}$ mesma linha de pensamento, para julgamento do pedido rescindente, consistente em reconhecer o vício na decisão de mérito e anulá-la, bastará o exame do feito originário em que se pretenda a rescisão. Quer no juízo de admissibilidade quer no juízo rescindente, a profundidade probatória se satisfaz plenamente com a análise dos autos.

Todavia, quanto ao pedido rescisório (rejulgamento), abre-se a possibilidade de amplitude dos elementos probatórios (oitiva de testemunhas, prova técnica pericial, ${ }^{157}$ depoimento pessoal das partes, ofícios para obtenção de informações de terceiros, inspeção judicial, dentre outros), admitindo todas as provas possíveis em direito, inclusive baixando em diligência de primeira instância no caso de necessidade de produção de provas orais. ${ }^{158}$

igual, quando do julgamento do REsp 222.445/PR, Rel. Ministro Sálvio de Figueiredo Teixeira. Efetivamente, dispõe o referido art. 130 do CPC que 'caberá ao juiz, de ofício ou a requerimento da parte, determinar as provas necessárias à instrução do processo, indeferindo as diligências inúteis ou meramente protelatórias'. Destarte, se a eg. Câmara reputou necessária a dilação probatória neste feito, inocorre óbice legal algum; ao reverso, há base legal para tanto, firmada no supramencionado cânone legal, ainda que as partes a tenham dispensado e o Juiz singular tenha entendido tratar-se, no caso, de matéria exclusivamente de direito. (...) Do quanto foi exposto, não conheço do recurso". "Prova. Dispensa pelas partes. Dilação probatória determinada pela $2^{\mathrm{a}}$ instância. Admissibilidade. Inexistência de preclusão. - Em matéria de cunho probatório, não há preclusão para o Juiz. Precedentes do STJ. Recurso especial não conhecido.” (STJ - REsp 262.978/MG, Rel. Ministro Barros Monteiro, 4ª Turma, v.u., DJ 30.06.2003. p. 251). Correspondem aos arts. 130 e 473 do CPC/1973, respectivamente, os arts. 370 e 507 do CPC/2015.

157 “In casu, foi deferida, pela Primeira Turma em acórdão da relatoria do e. Ministro Milton Luiz Pereira, então relator da presente Ação Rescisória, a realização de prova pericial destinada à demonstração de alegada falsidade do laudo em que se baseou o acórdão rescindendo para a fixação da indenização por desapropriação indireta." (STJ - EDclAgRgAR 1.291/SP, Rel. Ministro Luiz Fux, julgado em 24.11.2004, v.u., $1^{a}$ Seção, DJU 13.12.2004).

158 "Havendo necessidade de provas de audiência, estas serão realizadas não pelo Tribunal, e sim por delegação no juízo inferior. Os autos baixam à comarca onde as testemunhas devem ser ouvidas e, se as mesmas estiverem domiciliadas em comarcas diversas, os autos vão apenas para uma das comarcas, pois, para as outras, se expede carta de ordem. Esse é um procedimento adotado por todos os Tribunais para reduzir o prazo de tramitação da ação rescisória. Porque, se o processo tivesse que correr por todas as comarcas onde estão as testemunhas, provavelmente esse prazo previsto pela lei a ser estabelecido para a prática do ato pelo juiz relator pudesse ser excedido em muito. O juiz relator fixa um prazo de 45 a 90 dias para a prática do ato e, se houver motivo justo, poderá o prazo ser ampliado. Do contrário, os autos deverão ser devolvidos com a diligência cumprida”. (RIZZI, Luiz Sérgio de Souza. Da ação 
Assim, conforme o art. 972 do CPC/2015, é facultado ao relator determinar a produção de provas no juízo singular, ${ }^{159-160}$ de primeira instância, admitindo-se, portanto, a fase de dilação probatória para, após, seguirem-se as razões finais e o julgamento. ${ }^{161}$ Ao delegar as provas, nos termos do mesmo artigo, o relator fixará o prazo de um a três meses para a devolução dos autos. ${ }^{162}$

\subsection{VALOR DA CAUSA}

Naturalmente, em regra, na ação rescisória o valor da causa será o da causa de origem, com eventuais modificações ocorridas.

rescisória. Revista de Processo, v. 26. p. 192). Convém ressaltar que, nos termos do art. 972 do CPC/2015, o relator poderá delegar a competência, fixando o prazo de um a três meses para a devolução dos autos.

${ }^{159}$ BARIONI, Rodrigo Otávio. A produção de provas em ação rescisória. In: MEDINA, José Miguel Garcia; CRUZ, Luana Pedrosa de Figueiredo; CERQUEIRA, Luís Otávio Sequeira de; GOMES JÚNIOR, Luiz Manoel (Coord.). Os poderes do juiz e o controle das decisões judiciais: estudos em homenagem à Professora Teresa Arruda Alvim Wambier. São Paulo: RT, 2008. p. 1036.

160 "O texto do art. 972 do CPC/2015, autoriza que o relator, através de carta de ordem, delegue ao órgão que proferiu a decisão rescindenda o poder de coletar a prova a ser produzida. Por óbvio que a regra somente tem aplicação quando a decisão rescindenda tenha sido proferida por órgão hierarquicamente inferior àquele competente para o julgamento da rescisória. Se a rescisória busca a desconstituição de decisão proferida por órgão fracionário do próprio tribunal perante o qual ela se processa, não há sentido na aplicação da regra”. (MAZZEI, Rodrigo; GONÇALVES, Tiago Figueiredo. Primeiras linhas sobre a disciplina da ação rescisória no CPC/2015. In: DIDIER JR., Fredie (coord.); MACÊDO, Lucas Buril de; PEIXOTO, Ravi; FREIRE, Alexandre. Novo CPC - doutrina selecionada, v. 6: processo nos tribunais e meios de impugnação às decisões judiciais, p. 260-261).

${ }^{161}$ Atente-se, porém, que a ação rescisória não pode ser manejada como se fosse uma mera possibilidade de revisão após o prazo recursal, o seu objeto é distinto. Veja-se a seguinte ementa: “Ação rescisória. Alegação de violação a norma constitucional. Invocação do art. 485, V do Código de Processo Civil. Inocorrência. Ação rescisória não é nem pode ser sucedânea de recurso (embargos infringentes, ordinário, especial e/ou extraordinário). Ação improcedente”. (TJSP - Ação Rescisória 0.040.509-90.2011.8.26.0000, Rel. Des. Borelli Thomaz, Comarca: São Paulo $-6^{\circ}$ Grupo de Direito Público, julgado em 23.05.2012, registro 21.06.2012). Corresponde ao art. 485, inciso V, do CPC/1973 o art. 966, inciso V, do CPC/2015.

162 "Trata-se de prazo impróprio. A sua não observância não gera a imprestabilidade da prova. Bem instruir o processo é um dever judicial, estando, portanto, infenso à preclusão temporal”. (MARINONI, Luiz Guilherme; ARENHART, Sérgio Cruz; MITIDIERO, Daniel. Novo Código de Processo Civil comentado, p. 1032). 
O valor da inicial da ação rescindenda pode sofrer alteração pelo acolhimento da impugnação do valor da causa ou por aditamento da inicial, razão pela qual a ação rescisória acompanhará esse valor.

Uma dúvida que pode se estabelecer é quanto à atualização ou não do valor da causa. Deve ser corrigido monetariamente o valor da causa originária para compor o valor da causa rescindenda?

Nossos Tribunais são uníssonos em aceitar a repetição do valor simples, sem qualquer correção. Esse é um posicionamento que facilita o acesso à justiça, mas nada impede que a parte corrija o valor e atribua valor maior à causa, nem por isso será caso de extinção do processo nem retificação. $\mathrm{O}$ que não poderá é ser atribuída à causa valor menor que aquele da ação originária, sob pena de ser instado o autor a emendar e, não o fazendo, ocorrer a extinção da ação rescisória, sem o julgamento de mérito, nos termos do art. 321, caput e parágrafo único, do $\mathrm{CPC} / 2015$.

Outra dúvida que se pode formular é quando a causa comportar pluralidade de lides por cumulação de ações e a ação rescisória versar sobre apenas uma delas. Poderia ser reduzido o valor da causa para o patamar daquele pedido objeto da ação rescisória? Os Tribunais têm sido veementes em não aceitar essa redução, determinando a emenda e até a extinção do processo, se for o caso. ${ }^{163}$

Data venia, esse entendimento não se coaduna com o sistema processual vigente. $\mathrm{O}$ valor da causa deve ser atribuído nos limites do valor patrimonial das pretensões deduzidas. ${ }^{164}$ Se o autor houvesse dividido as lides em várias ações

${ }^{163}$ Confira: "Impugnação ao valor da causa. Ação Rescisória. Valor da causa originária devidamente atualizado. Não trazendo as parte valor líquido para definição do valor da causa na ação rescisória, em regra, tal montante deve ser orientado pelo valor originariamente indicado na fase de conhecimento, devidamente atualizado.” (TRF-4 - IVCAR 4858920164040000 PR 0000485-89.2016.404.0000, Rel. Rogerio Favreto, julgado em 30.06.2016, Terceira Seção, DE 14.07.2016).

164 "A jurisprudência desta Corte orienta que 'o requisito de depósito previsto no art. 488, II, do CPC deve considerar o valor da causa da ação rescisória, que é o mesmo da ação principal, corrigido monetariamente' (STJ - AR 1.277/SP, Rel. Ministro Luis Felipe Salomão, DJe 30.8.2011). Tal regra, entretanto, deve ser mitigada quando restar demonstrada a discrepância entre tal valor e o benefício econômico auferido com a decisão a ser rescindida.” (STJ - AgRg na Pet 5.144/MG, Rel. Ministro Hélio Quaglia Barbosa, DJ 24.5.2007). “O valor da causa da ação rescisória deve guardar correspondência com o da ação principal, corrigido monetariamente, salvo se existente proveito econômico diverso, desde que devidamente comprovado. Precedentes. 2. A impugnação ao valor da causa deve vir calcada em elementos concretos. 3. Impugnação ao valor da causa improcedente.” (STJ - Pet 7.104/SC, Ministro Paulo de Tarso Sanseverino, $2^{\text {a }}$ Seção, DJe 10.09.2012). 
individuais, então a ação rescisória de uma delas seria cabível pelo exato valor da causa de uma delas. Não pode o autor que optou por cumular as ações, tendo em vista a celeridade e concentração de atos em economia processual, vir a ser prejudicado. Uma ação distinta, cumulada ou não com outra, não pode mudar a natureza das coisas. Assim, é perfeitamente possível a atribuição do valor da causa rescindenda nos limites do pedido originário atingido pelo pedido rescindente, ou seja, regra essa que mais se aproxima do valor patrimonial perseguido na ação rescisória, ${ }^{165}$ e, apenas quando não houvesse valor patrimonial nos pedidos então seguiria o valor total da causa da ação antecedente.

Ainda, se a ação rescisória se volta apenas quanto à fixação dos honorários advocatícios, então o valor da causa será nos limites da fixação deste. Mantém-se a regra conferida pelo limite do valor patrimonial perseguido.

Por fim, entendemos que poderá ser majorado o valor da causa para além daquele atribuído à causa originária, pois o pedido rescisório poderia estar ilíquido quando da propositura da ação originária, em especial quando os danos são sucessivos, experimentados no curso da demanda. Se os danos já foram experimentados ao tempo da ação rescisória e o pedido rescisório se dirige a este aspecto, nada mais justo que seja ajustado o valor da causa para abranger o valor patrimonial deste pedido, ainda que seja majorado. ${ }^{166}$

\subsection{INDEFERIMENTO DA INICIAL}

Após a determinação judicial para emenda, uma vez não sendo observadas tais adequações, natural será o indeferimento da petição inicial.

"É de inteira conveniência que o relator não se omita no exercício rigoroso desse controle in limine litis, a fim de evitar o inútil prosseguimento de rescisória manifestamente inviável." ${ }^{\prime 167}$

\footnotetext{
${ }^{165}$ Nesse sentido, veja este julgado: "Ação Rescisória. Valor da causa. Ainda que o valor a ser atribuído à rescisória deva ser igual ao da demanda cuja sentença se pretende rescindir, impõe-se ressaltar que tal identidade não pode ser exigida nos casos em que se busca apenas a rescisão parcial da sentença. Ação rescisória que se conhece.” (TRT-2 - AR 7664008620125020000 SP 07664008620125020000, Rel. Regina Vasconcelos, julgado em 14.05.2013, SDI Turma, public. 21.05.2013).

166 "Ação rescisória. Impugnação ao valor da causa. Correspondência com proveito econômico pretendido pela autora.” (STJ - AgRg no REsp 1.276.430/DF, Rel. Ministro Sebastião Reis

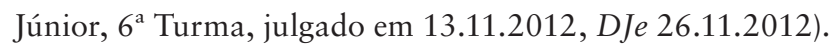

${ }^{167}$ MOREIRA, José Carlos Barbosa. Comentários ao Código de Processo Civil, 16. ed., v. V, p. 187.
} 
Hipóteses clássicas de indeferimento da inicial, não obstante inovações como a do art. 332 do CPC/2015, ${ }^{168}$ estão previstas no art. 330 do CPC/2015 e, em suma, referem-se ao não atendimento dos requisitos essenciais, em especial quanto à legitimidade para a propositura da ação rescisória e à possibilidade jurídica do pedido, à inépcia da inicial, à carência de ação.

A inicial da ação rescisória deverá ser distribuída com todos os documentos indispensáveis à propositura. Um desses documentos é o depósito de que trata o art. 968 , inciso II e $\mathbb{S} 3^{\circ}$, ambos do CPC/2015.

Portanto, excetuando-se a União, os Estados, o Distrito Federal, os Municípios, suas respectivas autarquias e fundações de direito público, ao Ministério Público, à Defensoria Pública e os beneficiários da justiça gratuita, que são isentos do depósito, também pode gerar o indeferimento da inicial quando se verificar a ausência do comprovante do depósito da multa no importe de $5 \%$ (cinco por cento) do valor da causa.

\subsection{PRINCÍPIO DA INSTRUMENTALIDADE DAS FORMAS}

A ação rescisória mal proposta deve ser sempre aproveitada se puder atingir o fim desejado, seja mesmo sem emenda da inicial, seja após determinada a emenda, quando for o caso. Aliás, determinar a emenda da inicial se torna obrigatório quando não preenchidos os requisitos genéricos da redação e documentação inicial. Não poderá o juiz, antes de determinar tal emenda, quando presente o fato ensejador, extinguir de pronto o feito (art. 321, caput e parágrafo único). ${ }^{169}$

168 "A Lei 11.277/2006 criou mais uma hipótese de indeferimento liminar da petição inicial, extinguindo o juiz o processo com sentença de mérito. Assim, nos termos do novo art. 285-A do CPC, 'quando a matéria controvertida for unicamente de direito e no juízo já houver sido proferida sentença de total improcedência em outros casos idênticos, poderá ser dispensada a citação e proferida sentença, reproduzindo o teor da anteriormente prolatada'." (MEDEIROS, Maria Lúcia Lins Conceição de. Considerações sobre o deferimento, a emenda e o indeferimento liminar da petição inicial, e o que as Leis 11.277/2006 e 11.280/2006 introduziram de novidade quanto ao tema. Doutrinas Essenciais de Processo Civil. São Paulo: RT, v. 3, out. 2011. p. 405). Corresponde ao art. 285-A do CPC/1973 o art. 332 do CPC/2015.

${ }^{169} \mathrm{Na}$ ação rescisória, trata-se de ação originária do tribunal, podendo ser aplicado o mesmo raciocínio dos recursos em geral. Nesse sentido, há precedente quanto aos recursos em geral, admitindo que "a falta pode ser declarada, de ofício, em segundo grau. $\mathrm{O}$ autor, porém, tem o direito de supri-la, nos termos do art. 284 do CPC. Recurso conhecido em parte e provido". (STJ - REsp 319.044/SP, Rel. Ministro Ruy Rosado de Aguiar, DJ 18.02.2002). Corresponde ao art. 284 do CPC/1973 o art. 321 do CPC/2015. 
Quando o pedido se dirigir contra a sentença de primeiro grau, equivocadamente, ${ }^{170} \mathrm{em}$ sendo o caso de pedido de desconstituição de acórdão substitutivo, o tribunal poderá conhecer o pedido diretamente, sem mesmo solicitar emenda da inicial ${ }^{171}$ - art. 485, c/c art. 321, ambos do CPC/2015 -, haja vista o flagrante erro material do pedido.

Nessa linha de pensamento, também se deve zelar pelo regular processamento da ação rescisória proposta em tribunal incompetente, determinando-se o redirecionamento na forma do art. $64, \mathbb{S} 3^{\circ}$, do CPC/2015, sendo reprovável

170 "Ação rescisória. Extinção do feito, sem julgamento do mérito, por impossibilidade jurídica do pedido. Entendimento no sentido de desconstituição do acórdão que a substituiu. Formalismo excessivo que afeta a prestação jurisdicional efetiva. Erro no pedido que não gerar nulidade, nem causa para o não provimento. Recurso extraordinário provido. Remessa ao TRT da $4^{\mathrm{a}}$ Região, a fim de que aprecie a ação rescisória, como entender de direito.” (STF - RE-AgR 395.662/RS, Rel. Originário: Ministro Carlos Velloso; Rel. para acórdão: Ministro Gilmar Mendes, $2^{\text {a }}$ Turma, DJ 23.04.2004).

${ }^{171}$ Reconhecendo a possibilidade de emenda da inicial inclusive após a citação, vide o seguinte aresto: "Processual civil. Extinção do processo. Emenda à inicial após a citação. Possibilidade. Abertura de prazo para suprimento da falha. Princípios da instrumentalidade das formas e da economia processual. Ratio essendi do artigo 284 do CPC. Precedentes jurisprudenciais do STJ. 1. Ação proposta em face de pessoa física supostamente representante da pessoa jurídica. A legitimidade para receber citação não arrasta a legitimatio ad causam, por influência do princípio societas distat singulis. 2. Não obstante, a jurisprudência desta Corte é pacífica no sentido de que a extinção do processo, sem julgamento do mérito, ante a ausência de documentos essenciais à propositura da ação, sem a concessão de prazo para que os autores emendem a inicial, importa em violação ao art. 284 do CPC. 3. É que, hodiernamente, é cediço que o rigor excessivo não se coaduna com os princípios da efetividade do processo e da instrumentalidade das formas, além de revelar verdadeira violação aos princípios constitucionais do devido processo legal e do acesso à justiça. 4. Deveras, sob o ângulo axiológico, a emenda da peça vestibular é um direito subjetivo do autor, de modo que não oportunizar a ele a emendar a inicial, no caso de ser a emenda possível, constitui um cerceamento do seu direito de defesa, haja vista o preconizado nas normas insertas nos incisos XXXV e LV do art. $5^{\circ}$ da Constituição Federal de 1988. (Precedentes jurisprudenciais desta Corte: AgRg no AG 504.270/RJ, desta relatoria, DJ 17.11.2003; REsp 101.013/CE, Rel. Ministro Hamilton Carvalhido, DJ 18.08.2003; AGRESP 330.878/AL, Rel. Ministro Castro Filho, DJe 30.06.2003; REsp 390.815/SC, Rel. Ministro Humberto Gomes de Barros, DJe 29.04.2002; REsp 384.962/MG, Rel. Ministro Felix Fischer, DJe 08.04.2002 e REsp 319.044/SP, Rel. Ministro Ruy Rosado de Aguiar, DJe 18.02.2002) 5. Recurso Especial improvido”. (STJ - REsp 671.986/RJ, Rel. Ministro Luiz Fux, $1^{\text {a }}$ Turma, julgado em 27.09.2005, DJ 10.10.2005, p. 232). Corresponde ao art. 284 do CPC/1973 o art. 321 do CPC/2015. 
a atitude de se julgar extinto o processo rescisório, pois, ainda que possa ser reproposta, uma vez que se dará a extinção sem julgamento de mérito, sempre envolverá transtornos desnecessários, podendo, inclusive, agravar o risco de operar-se a decadência bienal.

A efetividade da jurisdição não pode ser afetada pelo formalismo excessivo. Neste passo, o CPC de 2015 previu expressamente que a ação rescisória, após a devida emenda, deve ser remetida aos autos competentes (art. 968, $\left.\mathbb{S} 6^{\circ}\right) \cdot{ }^{172-173}$

O critério de norteamento das decisões judiciais deve se pautar na aplicação do princípio da instrumentalidade das formas, com o fito de aproveitamento e máximo rendimento ao ato praticado pela parte. ${ }^{174}$

\subsection{RESPOSTA DO RÉU}

A citação completa o actum trium personarum, representando a formação da relação jurídica processual, a formação do próprio processo, e determinando o início do prazo para a resposta do réu.

O processo deverá se desenvolver sob o crivo do contraditório, sendo que, após validamente citado e integrado à relação jurídica processual (com a citação), o réu passa a ter o ônus de se defender.

Contudo, isso não implica uma obrigação do réu de comparecer em juízo e apresentar sua resposta. Aí reside o fato de que se revela um ônus à parte se defender, já que, se assim não fizer, poderão lhe ser imputadas certas consequências, como os efeitos da revelia. Daí, após citado, o réu pode tomar uma das seguintes atitudes: a) ficar inerte, o que poderá ensejar os efeitos da revelia; b) apresentar resposta; e c) reconhecer a procedência do pedido.

${ }^{172}$ Neste sentido, "o legislador, considerando o modelo de processo cooperativo adotado pelo CPC/2015 e o princípio da primazia da análise do mérito (arts. $4^{\circ}$ e $6^{\circ}$ do CPC/2015), estabeleceu que, em tais hipóteses, o autor poderá emendar a inicial, a fim de que, em vez de indeferi-la, remetam-se os autos ao tribunal competente (art. $968, \$ 5^{\circ}$, I e II, $\$ 6^{\circ}, \mathrm{CPC} / 2015$ )". (ALVIM, Angélica Arruda (coord.) [et al.]. Comentários ao Código de Processo Civil, p. 1117).

${ }^{173}$ FLEXA, Alexandre; MACEDO, Daniel; BASTOS, Fabrício. Novo Código de Processo Civil: temas inéditos, mudanças e supressões, p. 678.

${ }^{174}$ MEDEIROS, Maria Lúcia Lins Conceição. Anotações sobre a competência para julgar ação rescisória. A ação rescisória e a suspensão da efetivação do julgado rescindendo, à luz da Lei 11.280/06, p. 1034. 
Optando por atuar no processo, após citado, o réu poderá oferecer, em petição escrita dirigida ao juiz da causa, as seguintes modalidades de resposta, simultaneamente (sob pena de incidência da preclusão consumativa): a) contestação; e b) reconvenção - arts. 335 e 343 do CPC/2015. Poderá apresentar impugnação à justiça gratuita, ao valor da causa e suscitar a incompetência relativa do juízo, mas estes reclames deverão estar presentes na contestação e não em peça apartada, como determinava o antigo CPC. ${ }^{175}$ Não mais são formados autos em apartado para a apreciação destas matérias defensivas.

Além disso, a reconvenção, igualmente, deverá estar presente na peça em que elaborada a contestação, nos termos do art. 343 do CPC/2015, e será apreciada no mesmo auto que esta, ou seja, não haverá a formação de um processo em apenso. ${ }^{176}$

O Código de Processo Civil de 2015 “esforçou-se para simplificar o procedimento para defesa, com o que procurou eliminar os incidentes processuais e concentrar o maior número possível de alegações na contestação.”177

\subsubsection{Prazo para contestação}

Nos termos do art. 970 do CPC/2015, o relator da ação rescisória é quem fixará o prazo para elaboração da defesa, entre 15 e 30 dias, dependendo da complexidade da causa. Havendo litisconsortes passivos que possuam diferentes procuradores, de escritórios de advocacia distintos, e sendo os autos físicos, o prazo será contado em dobro, entre 30 e 60 dias - art. 229 do CPC/2015. A não citação dos litisconsortes necessários poderá gerar anulabilidade do julgado.

175 "O novo Código eliminou as exceções e os incidentes de defesa: a incompetência relativa é matéria de contestação (art. 337, II, CPC), bem como a impugnação ao valor da causa (art. 337, XIII, CPC) e a impugnação ao benefício da gratuidade judiciária (art. 337, XIII, CPC). A reconvenção, que antes tinha de ser formulada em peça apartada, hoje tem de ser exercida na contestação (art. 343, CPC)." (MARINONI, Luiz Guilherme; ARENHART, Sérgio Cruz; MITIDIERO, Daniel. Novo Código de Processo Civil comentado, p. 429).

176 "A autonomia do modo de propositura, todavia, foi suprimida, devendo a reconvenção ser oferecida no corpo da contestação, prestigiando a simplificação do processo civil.” (FLEXA, Alexandre; MACEDO, Daniel; BASTOS; Fabrício. Novo Código de Processo Civil: temas inéditos, mudanças e supressões, p. 317).

177 MARINONI, Luiz Guilherme; ARENHART, Sérgio Cruz; MITIDIERO, Daniel. Novo Código de Processo Civil comentado, p. 429. 
Nos casos em que o réu seja Fazenda Pública, será computado em dobro o prazo para defesa, ou seja, entre 30 e 60 dias, na forma do art. 180 do CPC/2015.

Sob esse aspecto, poder-se-ia defender que o citado artigo se referia a prazo legal e que o prazo da ação rescisória seria um prazo judicial. Ocorre que o prazo judicial é uma espécie de prazo legal, pois o juiz nada mais faz que conferir a lei ao caso concreto, sempre se pautando por soluções que estejam conforme o direito positivado.

Ainda, poder-se-ia falar que o art. 970 do CPC/2015 conferiria discricionariedade ao magistrado para fixar prazo mais ou menos alargado, a depender da causa, em seus elementos objetivos e subjetivos. Data venia, o prazo foi fixado para todas as demandas rescisórias, e, como não houve vedação expressa, a aplicação do art. 970 do CPC/2015 deve ser mantida.

\subsubsection{Revelia}

O processamento da demanda sem a participação efetiva do réu, diga-se, sem contestação ou com a sua apresentação fora do prazo, embora haja a citação, fenômeno denominado como revelia (art. 344 do CPC/2015 - considerando como verdadeiros os fatos alegados pelo autor), mostra-se possível na ação rescisória. Porém, ainda que se declare a revelia na ação rescisória, ela não terá a mesma força como no processo comum, pois o pedido rescindente é infenso à confissão ficta; nele não existe esse efeito. Note-se que, no confronto da tese rescindenda com a coisa julgada (matéria de ordem pública), há inibição do efeito material da confissão ficta para anular a decisão de mérito, atuando como se existisse uma pré-contestação, ou seja, incute no julgador uma presunção de veracidade do julgado. ${ }^{178}$

Aliás, o julgado transitado em julgado se afeiçoa à matéria de ordem pública, pois é evidente o interesse na manutenção da coisa julgada em geral, que

\footnotetext{
178 "Se o réu for revel, não se verificará, necessariamente, o efeito previsto no 344, in fine, do CPC/2015 (segundo o qual 'presumir-se-ão verdadeiras as alegações de fato formuladas pelo autor'). Decidiu-se que 'mera omissão processual, decorrente do descumprimento de um ônus [no caso, de contestar], não pode gerar efeitos de grande relevância a ponto de eliminar a coisa julgada, instrumento a serviço da ordem pública e do bem comum, da paz e da tranquilidade sociais' (Ext. 2. ${ }^{\circ}$ TACivSP, AR 205.584-7, rel. Des. Macedo Cerqueira, j. 09.12.1987, RT 626/121). À luz da nova lei processual, pode-se dizer que a hipótese se encarta no que prevê o inc. IV, in fine do art. 345 do CPC/2015." (MEDINA, José Miguel Garcia. Novo Código de Processo Civil comentado, p. 1399).
} 
apenas pode cair ante a excepcionalidade rescisória. ${ }^{179} \mathrm{O}$ pedido rescindente se dirige à anulação do julgado e, portanto, quando procedente esse pedido, inicia-se a outra fase, que será o rejulgamento da causa. Nesse pedido, no âmbito do juízo rescisório, uma vez já anulada a sentença, incidirá a revelia em sua plenitude, caso escassas as provas no processo originário e não tenha nele sido produzida a ampla dilação probatória. Assim, o Tribunal poderá dispensar a dilação probatória e efetuar o julgamento do pedido rescisório com base na revelia.

\subsubsection{Reconvenção}

A reconvenção é a ação do réu contra o autor, proposta no mesmo processo em que está sendo demandado, ${ }^{180}$ igualmente passível de acontecer no processo rescisório, haja vista os casos em que haja sucumbência recíproca no processo de origem e os vícios rescisórios atendam aos interesses de cabimento tanto ao autor como ao réu.

Logo, a reconvenção tem todos os requisitos de uma petição inicial, inclusive as condições da ação e os pressupostos processuais. ${ }^{181} \mathrm{Na}$ contestação, o réu se insurge contra o pedido do autor, resiste a ele, enquanto na reconvenção há um verdadeiro contra-ataque, onde o réu, na mesma relação processual, instaurará uma nova lide (cúmulo de lides), fazendo um pedido contra o autor.

Havendo reconvenção, as partes passarão a ser autor e réu ao mesmo tempo. Saliente-se que cabe reconvenção em rescisória. A premissa necessária é a de que a reconvenção tenha também a natureza de ação rescisória e também se volte

\footnotetext{
${ }^{179}$ Sobre esse tema, aliás, deliberou o Colendo Superior Tribunal de Justiça que não pode o juiz deixar de reconhecer a revelia, quando presentes os requisitos. Veja-se a ementa: "a falta de contestação faz presumir os fatos alegados pelo autor, desde que se trate de direito disponível. Deixando de reconhecê-lo, contrariou o acórdão o disposto no art. 319 do CPC”. (STJ - REsp 8.392/MT, $3^{\text {a }}$ Turma, v.u., Rel. Ministro Eduardo Ribeiro, julgado em 29.4.1991, DJU 27.5.1991. p. 6963). Corresponde ao art. 319 do CPC/1973 o art. 344 do $\mathrm{CPC} / 2015$.

180 “A reconvenção é uma nova ação, pois aciona o judiciário a proferir uma resposta às pretensões formuladas pelo réu. A peculiaridade reside em que não forma um novo processo. A ação principal e a reconvenção terão um processamento conjunto e serão julgadas por uma só sentença. Haverá duas ações em um único processo.” (GONÇALVES, Marcus Vinicius Rios. Direito processual civil esquematizado, p. 442-443).

${ }^{181}$ KLIPPEL, Rodrigo; BASTOS, Antônio Adonias. Manual de processo civil, p. 429.
} 
contra o mesmo julgado, apenas se modificando quanto ao objeto em outro capítulo da decisão rescindenda. ${ }^{182}$

\subsubsection{Reconhecimento do pedido}

O reconhecimento expresso ${ }^{183}$ da procedência do pedido deve ser lido cum grano salis, ante os argumentos já expostos na caracterização da revelia.

$\mathrm{O}$ magistrado deve estar atento a eventuais manobras de conluio entre as partes para desfazer uma sentença legitimamente proferida. Isso porque, não raro, após a sentença ocorrem situações em que direito de terceiros acaba por interferir no direito adquirido pela coisa julgada, fazendo com que as partes se unam com o fim de lesar direito de terceiro. ${ }^{184}$

${ }^{182}$ Colaciona-se um caso em que houve conhecimento da reconvenção em ação rescisória: "Ação Rescisória. Reconhecida a afronta aos artigos 20, $\mathbb{S} 3^{\circ}$, e 21 ambos do Estatuto Processual. Verba honorária fixada em $15 \%$ sobre o valor atualizado da condenação. Reconhecimento da sucumbência parcial e recíproca. Condenação da ré em 30\%, e 70\% a cargo da autora. Reconvenção julgada improcedente. Condenação da ré reconvinte ao pagamento das despesas processuais, fixadas em $10 \%$ sobre o valor atualizado, além da perda do depósito previsto no artigo 488, II do Código de Processo Civil. Ação rescisória procedente. Reconvenção improcedente”. (TJSP - Ação Rescisória 61.077-45.2002.8.26.0000, cobrança seguro empresarial, Rel. Natan Zelinschi de Arruda, 4a Câmara de Direito Privado, julgado em 25.03.2004, registro 02.04.2004). Corresponde ao art. 488, inciso II, do CPC/1973 o art. 968, inciso II, do $\mathrm{CPC} / 2015$.

183 “Ação rescisória, fundada no artigo 485, incisos V e IX, do Código de Processo Civil. O acórdão atacado reconheceu que a extinção do feito com base no artigo 269, inciso III, do Código de Processo Civil não é a fundamentação adequada ao caso em tela, vez que não houve transação nos autos, bem como o reconhecimento do pedido, pleito da parte apelante, pois o reconhecimento do pedido deve ser expressamente proclamado nos autos, para que, assim, o juiz possa sentenciar com base no artigo 269 inciso II do Código de Processo Civil, cabendo ao magistrado se utilizar do artigo 269, I, do Código de Processo Civil, extinguindo o feito com resolução do mérito, acolhendo o pedido autoral. Como a parte ré já cumpriu a obrigação de fazer requerida pelo autor na petição inicial, só resta ao juiz condená-la ao pagamento das custas e no pagamento dos honorários advocatícios.” (TJRJ - Ação Rescisória 0.007.54624.2011.8.19.0000, Órgão Especial, Des. Edson Scisinio Dias, julgado em 30.07.2012). Correspondem aos arts. 485, V e IX, e 269, I, II e III, do CPC/1973, respectivamente, o art. 966, V e VIII, e o art. 487, I e III, $a$ e $b$, do CPC/2015.

${ }^{184}$ Uma das hipóteses de cabimento da ação rescisória é o dolo da parte vencedora, não importando que esteja em conluio com a parte vencida. Nesses casos, inclusive, abre-se a possibilidade de ação rescisória de ação rescisória, proposta pelo terceiro ou pelo Ministério Público: “o art. 485 do CPC possui redação clara no sentido de que é cabível a demanda se ocorrer (...) dolo da 
Concluindo, ressalvados os subterfúgios para utilização do Poder Judiciário para fins escusos, será perfeitamente admitido o reconhecimento do pedido na ação rescisória. ${ }^{185-186}$

parte vencedora”. (TJRJ - Ação Rescisória n. 0029.325-98.2012.8.19.0000, 3 ª Câmara Cível, Des. Helda Lima Meireles, julgado em 26.07.2012). Corresponde ao art. 485 do CPC/1973 o art. 966 do CPC/2015.

${ }^{185}$ Nesse sentido é o seguinte julgado: “Ação rescisória. Reconhecimento do pedido. Procedência da ação. Julga-se procedente a ação rescisória quando o réu, ao ser citado, vem aos autos dizer que já concordou com o pedido do autor quando da oposição de embargos à execução do acórdão rescindendo. Acórdão. Vistos e relatados estes autos em que são partes as acima indicadas, decide a Egrégia $3^{a}$ Seção do Tribunal Regional Federal da 4a Região, por unanimidade, julgar procedente a ação rescisória, nos termos do relatório, votos e notas taquigráficas que ficam fazendo parte integrante do presente julgado". (TRF - $4^{\text {a }}$ Região - Ação Rescisória 2009.04.00.035059-2/RS, Rel. Juiz Federal Loraci Flores de Lima julgado em 03.02.2011, DE 15.02.2011).

${ }^{186}$ Nesse ínterim, veja o presente julgado: “Ação Rescisória. Decisão proferida em ação acidentária. Incompetência absoluta da Justiça Federal. Reconhecimento da procedência do pedido. 1. As ações acidentárias relativas à concessão, restabelecimento e/ou revisão dos respectivos benefícios são da competência da Justiça Estadual, conforme dispõe o inciso I do art. 109 da Constituição Federal de 1988. 2. Homologado o reconhecimento da procedência do pedido. Ação rescisória julgada procedente.” (TRF-4 - AR 7367320174040000 RS, Rel. Jorge Antonio Maurique, julgado em 27.06.2018, $3^{\mathrm{a}}$ Seção). 
